\title{
Review
}

\section{Structural heterogeneity of membrane receptors and GTP-binding proteins and its functional consequences for signal transduction}

\author{
Fritz BOEGE ${ }^{1}$, Eberhard NEUMANN ${ }^{2}$ and Ernst J. M. HELMREICH ${ }^{1}$ \\ 1 Department of Physiological Chemistry, University of Würzburg, Federal Republic of Germany \\ 2 Faculty of Chemistry, University of Bielefeld, Federal Republic of Germany \\ (Received June 18, 1990) - EJB 900705
}

Recent information obtained, mainly by recombinant cDNA technology, on structural heterogeneity of hormone and transmitter receptors, of GTP-binding proteins (G-proteins) and, especially, of G-protein-linked receptors is reviewed and the implications of structural heterogeneity for diversity of hormone and transmitter actions is discussed. For the future, three-dimensional structural analysis of membrane proteins participating in signal transmission and transduction pathways is needed in order to understand the molecular basis of allosteric regulatory mechanisms governing the interactions between these proteins including hysteretic properties and cellcybernetic aspects.

Thanks to recombinant DNA technology, there has been a recent flood of structural information on membrane receptors, G-proteins and target enzymes [for reviews see Gilman (1987), Casey and Gilman (1988), Lefkowitz and Caron (1988), Levitzki (1988), Neer and Clapham (1988), Pfeuffer and Helmreich (1988), Freissmuth et al. (1989), Gilman (1989), Birnbaumer et al. (1989), Strader et al. (1989), Birnbaumer (1990), Birnbaumer et al. (1990)]. This work brought to light not only a high degree of structural heterogeneity but also interesting structural relationships.

The consequences of the extensive structural heterogeneity among the proteins involved in signal transmission are farreaching. Accordingly, this review deals mainly with the implications of structural heterogeneity, mainly of G-proteins and G-protein-linked receptors, for the diversity and multiplicity of signal transmission and cellular regulation mechanisms.

Correspondence to E. J. M. Helmreich, Department of Physiological Chemistry, University of Würzburg School of Medicine, Koellikerstrasse 2, W-8700 Würzburg, Federal Republic of Germany

Abbreviations. AcCh, acetylcholine; $\mathrm{nAcChR}$, nicotinic acetylcholine receptor; $\mathrm{GABA}_{\mathrm{A}}$, receptor which binds $\gamma$-aminobutyric acid (GABA). [Purinergic (P) ligands ATP, ADP, AMP and adenosine, cf. Burnstock, 1978; Burnstock and Kennedy, 1985]; G-proteins, heterotrimeric GTP-binding proteins composed of $\alpha-, \beta$ - and $\gamma$-subunits; $G_{s}$, stimulatory $G$-protein; $G_{i}$, inhibitory $G$-protein; $G_{o}$, brainderived $G$-protein; $G_{t}$ (transducin), rhodopsin-linked G-protein etc.; ras, rho, etc., small monomeric G-proteins; GAP-43, growth-associated protein with $M_{\mathrm{r}} 43000$; ARF, ADP-ribosylating factor; GAP, GTPase-activating protein; GEF, GDP-exchange factor; GTP $\gamma$ S $]$, guanosine 5' $O$-(3-thiotriphosphate); PtdIns, phosphatidyl 1-inositol; MDCK cells, Madin-Darby canine kidney cells; $\mathrm{GH}_{4} \mathrm{C}_{1}$, pituitary cell line from the rat; BALB-c-3T3 cells are from a mouse fibroblast cell line; carazolol, 1-(9H-carbazol-4-yloxy)-3-[(1-methylethyl)amino]-2-propanol is a $\beta$-adrenergic blocker; CGP- 12177 is a $\beta$-adrenergic antagonist and the Ciba Geigy product 12177, 4-[3-( $t$-butylamino)-2-hydroxypropoxy]benz-imidazol-2-on.
The selection of examples to support the arguments advanced in this review is quite arbitrary and is heavily biased towards the $\beta$-adrenoceptor/G-protein/adenylate cyclase. In addition, some regulatory properties of the acetylcholine receptor are also discussed. The reasons for this bias are to be found in the research interests of the authors. For the reader interested in additional and more detailed information regards the topic under discussion, recent reviews by Birnbaumer et al. (1990) and Bourne et al. (1990) are recommended.

\section{Structural properties of membrane receptors}

Many hormones, neurotransmitters and growth factors act as extracellular signals which bind first to receptors at the cell membrane surface. In this context, we shall restrict our discussion to plasma membrane receptors and signal transduction mechanisms originating from them and will not consider steroid hormones. The receptors we are dealing with are transmembranous glycoproteins. On binding a hormone, a neurotransmitter or any agonist, the receptor is activated in a manner which is not yet understood at the molecular level; the phenomenological consequences of activation are better known. Pharmacologists have classified receptors according to the ligands which they bind (Ahlquist, 1948). Accordingly, one has to distinguish between adrenergic, cholinergic, histaminergic, dopaminergic receptors, and so forth. Tacitly, it was implied that a receptor activated by an agonist of a given class initiates a sequel of biological events which are unique for this type of ligand. However, newer evidence suggests that different receptors may have similar actions and conversely a given receptor class can have multiple functions (see Fig. 1), thus casting doubts on the validity of the above classification. But in the future, the structural information already available and still forthcoming could serve as a basis for a new classification scheme. 


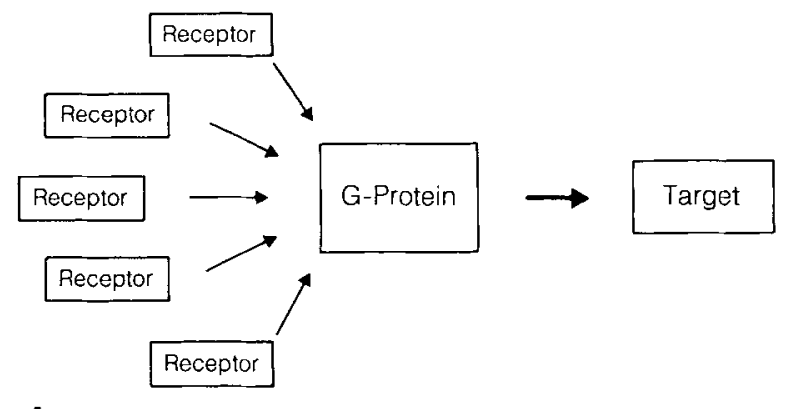

A

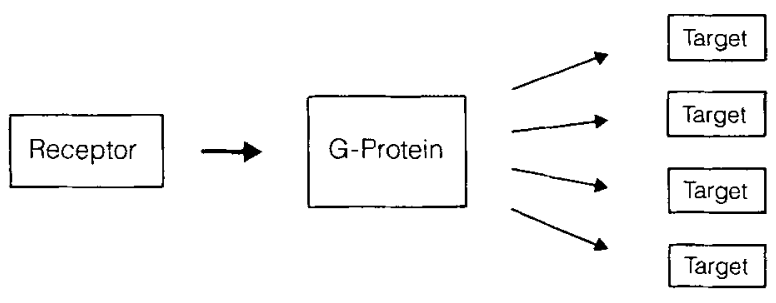

B

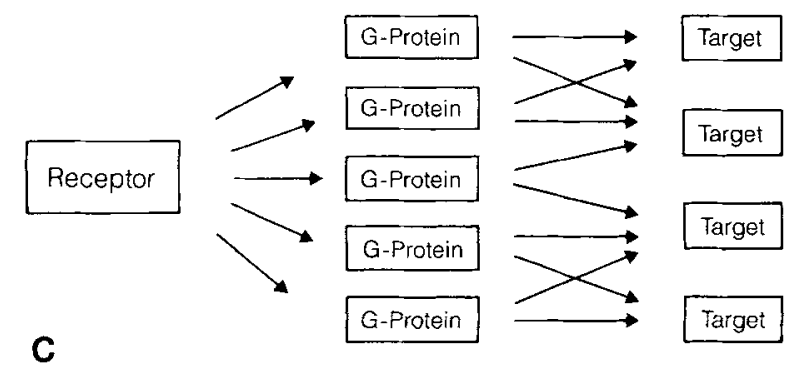

Fig. 1. Multiplicity of receptor-G-protein-target activation. A similar diagram of the information flow through G-protein-coupled signal transduction pathways has been presented by Birnbaumer et al. (1989, 1990)

Based on their structures, membranous proteins, including membrane receptors, can already be divided in two main classes: receptors where the polypeptide chains span the membrane only once and receptor polypeptides which span the membrane several times. To the first group belong receptors with intrinsic tyrosine kinase activity, such as the receptors for insulin (see Olson and Lane, 1989), insulin-like growth factors, epidermal growth factor, platelet-derived growth factor and others. The second group comprises the superfamily of the 'ligand-gated' ion channels including the nicotinic acetylcholine receptor (nAcChR; see Stroud et al., 1990) and the $\gamma$-aminobutyric acid (GABA) receptors (see Schofield et al., 1987) and all receptors whose actions are amplified by GTP-binding proteins. Receptors expressing tyrosine kinase activity bind polypeptide hormones and growth factors.

There is considerable evidence that, in the case of receptors with tyrosine kinase activity, activation on binding of an appropriate ligand initiates aggregation (for reviews see Czech, 1985, and Böni-Schnetzeler et al., 1986). For example, EGF induces receptor oligomerization and triggers auto-phosphorylation (Zidovetzki et al., 1981; Schlessinger, 1986; Cochet et al., 1988). Receptor oligomerization has also been observed with other peptide binding receptors (cf. Brenner et al., 1985; Sharon et al., 1986) and in the case of ion-channelforming receptors (Schofield et al., 1987).

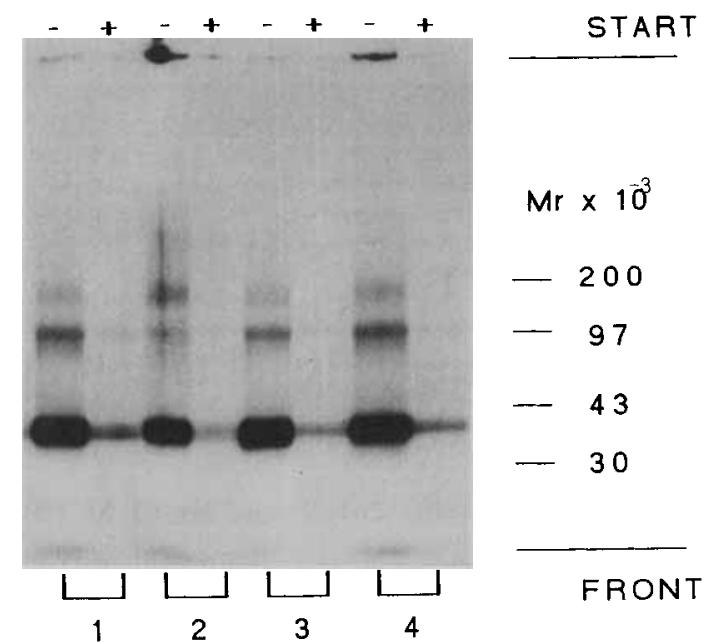

Fig. 2. Crosslinking of turkey erythrocyte $\beta_{1}$-adrenoceptors. (Based on unpublished experiments of Boege 1990.) Turkey erythrocyte membranes were treated with bis(sulfosuccinimidyl)suberate according to Staros (1982). For that purpose, $0.6 \mathrm{mg} / \mathrm{ml}$ membrane protein was incubated with $50 \mu \mathrm{M}$ bis(sulfosuccinimidyl)suberate in $50 \mathrm{mM}$ Hepes $\mathrm{pH} 7.5,200 \mathrm{mM} \mathrm{NaCl}$ and $10 \mathrm{mM} \mathrm{MgCl}_{2}$ for $1 \mathrm{~h}$ at room temperature. The reaction was terminated by addition of $0.1 \mathrm{vol}$. $500 \mathrm{mM}$ Tris/ $\mathrm{HCl} \mathrm{pH} 7.5$. $\beta_{1}$-Adrenoceptors in the membrane preparations were tagged radioactively by treatment with the photoaffinity reagent, $\left[{ }^{125}\right]$ iodocyanopindolol-azide- $2(2.2 \mu \mathrm{Ci} / \mathrm{mmol})$, synthesized and applied as described by Burgermeister et al. (1982). After completion of the reaction, the membrane proteins were analyzed by SDS/ PAGE under non-reducing conditions in $4-12 \%$ polyacrylamide gradient gels. Rabbit skeletal muscle myosin $\left(M_{\mathrm{r}} \approx 200000\right)$, rabbit skeletal muscle phosphorylase $b\left(M_{\mathrm{r}} \approx 97000\right)$, ovalbumin $\left(M_{\mathrm{r}} \approx 43000\right)$ and carbonic anhydrase $\left(M_{\mathrm{r}} \approx 30000\right)$ were used as $M_{\mathrm{r}}$ markers. Lanes 1, control, not activated or crosslinked; lanes 2, crosslinked; lanes 3 , activated with $1 \mu \mathrm{M} l$ (-)isoproterenol for $1 \mathrm{~h}$ at $30^{\circ} \mathrm{C}$, not crosslinked; lanes 4 , activated as in lane 3 followed by crosslinking as in lane $2 ;(+)$ nonspecific incorporation of the photoaffinity label remaining after blockade of the receptor with $20 \mu \mathrm{M}$ CGP 12177 , a $\beta$-receptor-specific antagonist

Regarding $\beta$-adrenoceptors in intact cells in tissue culture, a patched non-homogeneous distribution in the plasma membrane was observed in a temperature range of $4-37^{\circ} \mathrm{C}$ using the technique of fluorescence recovery after photobleaching (Henis et al., 1982). In addition, Fraser et al. (1987) have detected in the course of purification of $\beta$-adrenoceptors small amounts of receptor dimers and tetramers.

We have studied aggregation of $\beta_{1}$-adrenoceptors in turkey erythrocyte membranes ( $F$. Boege, unpublished experiments, 1990) using bis(sulfosuccinimidyl)suberate as crosslinking reagent. The same reagent was used to crosslink EGF-receptor dimers (Fanger et al., 1989). But, in contrast to the EGF receptor, the $\beta_{1}$-adrenoceptor from turkey erythrocytes did not form dimers or oligomers on hormone binding and activation. As demonstrated in Fig. 2, a small amount of the $\beta_{1}$ receptor appears to be preaggregated in the absence of ligand. However, stimulation by the agonist did not alter the quarternary structure of the $\beta_{1}$-adrenoceptor and neither did crosslinking of the activated receptor trap aggregated forms of the receptor, whereas, under comparable conditions, spectrin dimers were crosslinked with great efficiency. Even considering that some of the $\beta_{1}$-receptors may not have reacted with the crosslinking reagent, it seems highly unlikely on the basis of these experiments that receptor aggregation plays a major role in activation of $\beta_{1}$-adrenoceptors by catecholamines. 
In the case of the insulin receptor, phosphorylation sites are on the carboxy-terminal part of the $\beta$-chain; autophosphorylation is thought to activate the tyrosine kinase and to result in phosphorylation of substrate proteins, among which could be a serine-threonine-specific protein kinase (or protein phosphatase) which could trigger a whole complex phosphorylation-dephosphorylation cascade (Czech et al., 1988). At present, however, it is not clear on a molecular level how autophosphorylation activates the receptor-associated tyrosine kinase, nor can one say whether a phosphorylation cascade initiated by tyrosine phosphorylation is the only, or even the major, mechanism of signal transduction by this kind of receptor. For example, a participation of G-proteins in the action of insulin and epidermal growth factor has been invoked (cf. Heyworth et al., 1985; Ciaraldi and Maisel, 1989; Kelvin et al., 1989; Nair et al., 1989).

The structure of the receptors which span the membrane more than once has been modelled in analogy to the structure of bacteriorhodopsin, although a high-resolution three-dimensional structure of any one receptor of this kind has not yet been forthcoming. Bacteriorhodopsin belongs to a class of halobacterial retinal-binding proteins which can utilize light energy to drive an ATP-generating proton pump. This class of membrane proteins, to which among others also belong the $\beta$-adrenoceptors and rhodopsin in the rod outer segment membranes of the retina, is assumed to have seven membranespanning domains. One should be aware, however, that in the absence of a three-dimensional structure, structural details based on the model with seven membrane-spanning domains must remain conjectural for any receptor (see Lodish, 1988; Hartmann et al., 1989). It is mainly based on hydrophilicity/ hydrophobicity profiles and the accessibility of the receptor in the membrane to protease digestion.

In the case of bacteriorhodopsin, Henderson and Unwin (1975) originally visualized, by low-energy electron diffraction at $0.6-\mathrm{nm}$ resolution, seven transmembrane $\alpha$-helices. Henderson et al. (1990) have recently presented a refined structure at 0.35 -nm resolution. In the case of the $\beta_{1-}, \beta_{2^{-}}$and $\alpha_{1}$-adrenoceptors and for a similar protein, G21, which is a serotonin receptor subtype, a structure with seven highly conserved transmembraneous segments, each with $20-28$ hydrophobic amino acids linked by three external and three cytoplasmic loops, has been proposed (see Fig. 3). Cytoplasmic loops $\mathrm{C} 1$ and $\mathrm{C} 2$, with the corresponding transmembranous domains and the outside loops, are conserved. The conserved regions on the outside and parts of the transmembranous domains are assumed to be crucial for ligand binding. This is mainly based on results from site-directed mutagenesis studies, deletion mutants and experiments with site-specific peptides (Dixon et al., 1987; Strader et al. 1987a, b, 1988; Cotecchia et al., 1988, 1990; Fargin et al., 1988; Hamm et al., 1988; Kobilka et al., 1988; O’Dowd et al., 1988; Regan et al., 1988; Fraser, 1989; Palm et al., 1989, 1990; Dohlman et al., 1990).

Heithier et al. (1988) have probed the environment of the ligand binding site with a fluorescent specific $\beta$-adrenergic antagonist which was environmentally sensitive. Tota and Strader (1990) have characterized the binding site of a hamster $\beta_{2}$-adrenergic receptor expressed in baculovirus-infected Spodoptera frugiperda insect cells with the antagonist carazolol as fluorescent probe. However, the results obtained with the fluorescent and more hydrophilic CGP-12177 derivative (Heithier et al., 1988) and the hydrophobic carazolol (Tota and Strader, 1990) were quite opposite; whereas the latter sensed a very hydrophobic environment, a more hydrophilic binding site was detected by the former probe. The third, large cytoplasmic loop, C3, and the cytoplasmic carboxy-terminal part differ among the members of this receptor family and parts of these structures could therefore be responsible for receptor-specific interactions with G-proteins (for additional information see also Dixon et al., 1988; Lefkowitz and Caron, 1988; Strader et al., 1989).

The regions of the $\beta$-adrenoceptor important for G-protein coupling are the $\mathrm{N}$ - and C-terminal segments of the third intracellular loop (see Fig. 3). However, the primary sequences of these regions are divergent among G-protein-coupled receptors. Cheung et al. (1989) and Huang et al. (1990) have suggested that a putative secondary structure motif of these regions, namely an amphipathic $\alpha$-helical structure, which is conserved among all G-protein-coupled receptors whose sequences have been determined, is responsible for receptorG-protein interaction. Polyanions, which inhibit receptorG-protein coupling, are believed to interact with the largely cationic face of the putative amphipathic helix.

All receptors which couple to G-proteins are glycoproteins with glycosylation sites at the $\mathrm{N}$-termini and phosphorylation sites at the cytoplasmic carboxy terminal domain to which $\beta$ arrestin binds (see Boege et al., 1988; Lohse et al., 1990). The human $\beta_{2}$-adrenoceptor is also linked to a fatty acid, is has a palmitoyl residue (O'Dowd et al., 1989). Mutant receptor molecules in which cysteine 341 was replaced by glycine no longer have this residue and showed decreased activation of adenylate cyclase in response to isoproterenol. Since cysteine 341 is conserved in every G-protein-coupled receptor examined, all members of this receptor family might be palmitoylated. Acylation of cysteine 341 might be expected to promote binding of this region to the membrane, thus creating a fourth intracellular loop which is assumed also to be involved in G-protein binding, but how fatty acylation aids in the formation of a functional G-protein binding site is not known (James and Olson, 1990).

The largest sequence similarity $(54 \%)$ is found between $\beta_{1}$ - and $\beta_{2}$-adrenoceptors. The overall sequence similarity is matched by similar binding properties towards a series of catecholamines. The muscarinic acetylcholine receptor subtypes M1 and M2 are more distant on the basis of their primary structure (Lefkowitz and Caron, 1988). But despite the structural similarities, the separate genes for the $\beta_{1}$ - and $\beta_{2}$-receptors, which have no introns, do not hybridize (Frielle et al., 1987).

The number of members of this family of receptor genes is still growing: a 343-amino-acid-containing protein, named rat thoracic aorta protein, is a candidate for a G-proteincoupled receptor (Ross et al., 1990). A human $\left(\beta_{2}\right)$ adrenoceptor was cloned and expressed in Escherichia coli (Marullo et al., 1988) and a human $\beta_{3}$-adrenoceptor was detected using the polymerase chain reaction (Emorine et al., 1989). One of the members of this adrenoceptor class is closely related to the serotonin receptor. Two other genes apparently code for a new subfamily of G-protein-coupled receptors which have very short non-glycosylated $\mathrm{N}$-terminal additions.

G-protein-coupled receptors are found at every level of the evolutionary scale. G-protein-linked receptors are highly adaptable with respect to both the chemical structure of the ligand which they accomodate and with respect to their function. It now seems that several G-protein-linked neural receptors which are coupled to phospholipase $\mathrm{C}$ and catalyze phosphatidylinositol 4,5-bisphosphate hydrolysis, including the 5-hydroxytryptamine and the mas-oncogene-associated 


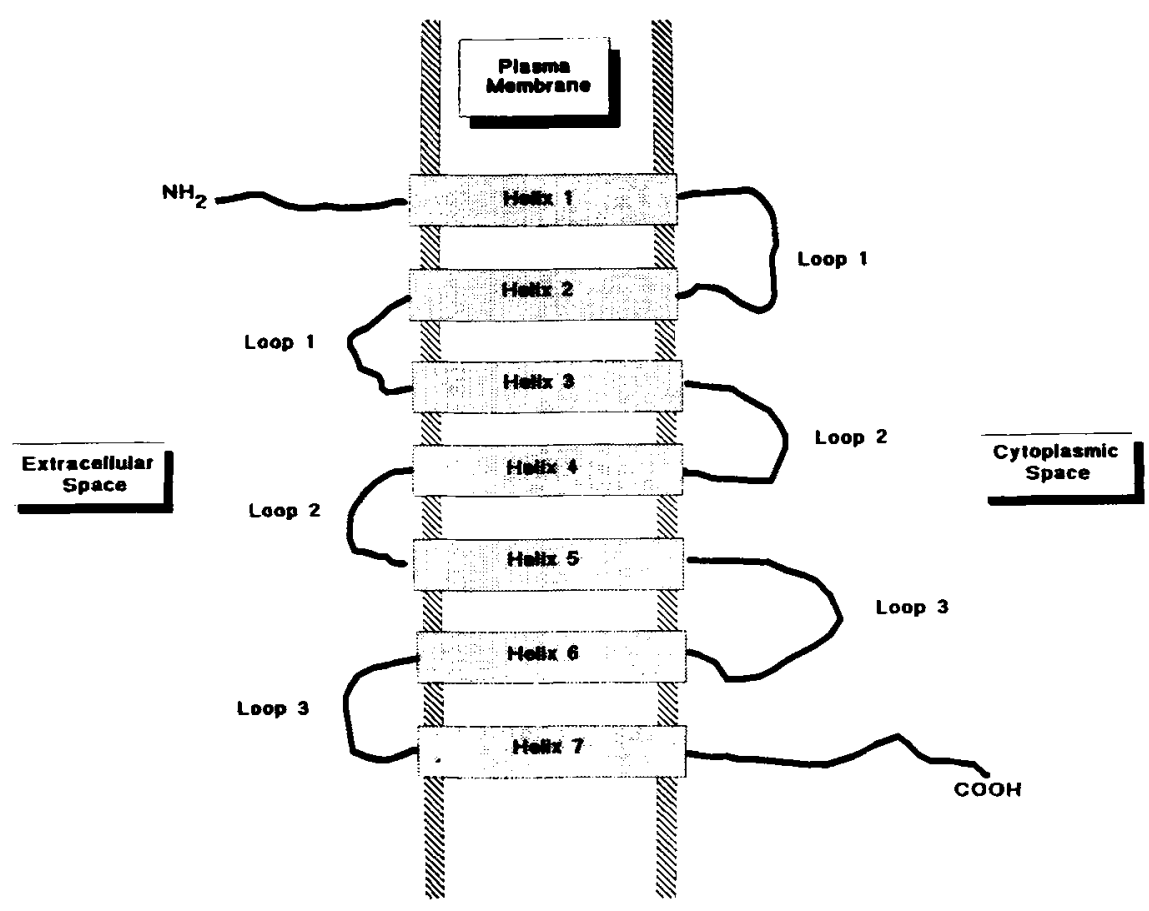

Fig. 3. Hypothetical and highly schematic membrane topology of G-protein-linked receptors. The membrane orientation based on hydrophobicity indicates seven membrane-spanning helices joined by three extracellular (left side) and three cytoplasmic loops (right side) (see also Strader et al., 1989)

angiotensin receptor, have mitogenic potentials. All the muscarinic receptors so far identified can apparently stimulate DNA synthesis. This suggests that receptors coupled to different signalling pathways, for example muscarinic acetylcholine receptors which also participate in the inhibitory control of adenylate cyclase through $G_{i}$, may also be involved in cell proliferation.

Recent evidence points to possible connections between G-protein- and growth-factor-dependent mechanisms. Data obtained with mouse BALB-c-3T3 embryonic cells suggest cooperative effects on cell proliferation of classical G-proteindependent signal pathways and of growth-factor-receptor-associated tyrosine kinases (see Dumont et al., 1989; Kojima et al., 1989). Hanley (1989) has actually suggested, while discussing these and other results, that all the important signal transduction pathways controlled by G-protein-coupled receptors may be mitogenic. To this group belongs a number of receptors for functionally different hormones. Among them are receptors for catecholamines and cholinergic ligands and biogenic amines such as serotonin and dopamine, receptors for substances K (Masu et al., 1987) and P (Yokota et al., 1989) and luteinizing hormone (Loosfelt et al., 1989; McFarland et al., 1989) as well as rhodopsin, the light receptor in visual signal transmission (Stryer, 1986) and the receptors for the mating factor of yeast (Dietzel and Kurjan, 1987; Herskowitz and Marsh, 1987) and for the chemotactic cAMP in Dictyostelium discoideum (van Haastert, 1987). This list is incomplete (see also Barnard, 1988; Boulay et al., 1990). Birnbaumer et al. (1990) have listed about 80 receptors activated by $\mathrm{G}$-proteins. In this review, the reader will find a more complete list of references.

One major reason for the existence of the bewildering number of receptor subtypes based upon different DNA sequences is tissue specialization. Some of the isoforms are also likely to be developmental specializations. But this is not the only reason for functional diversity. The adrenoceptor family is an example: $\alpha_{1-}, \alpha_{2^{-}}, \beta_{1^{-}}$and $\beta_{2}$-adrenergic receptors are distinguished by the chemical specificity of their ligand binding. However, this pharmacological classification tells us little about the biological function: $\alpha_{1}$ - and $\alpha_{2}$-receptor subtypes and probably also $\beta$-adrenoceptors can have multiple and diverse functions: functional diversity may be due to the fact that each receptor subtype couples to a different G-protein or it may depend on whether one receptor couples with more than one distinct G-protein (Fig. 1 C). A less likely possibility would be that one given G-protein interacts with more than one cellular target (Fig. 1 B).

The group of transmembrane receptors which span the membrane several times also includes the ligand-gated ion channels. Functionally, these membrane glycoproteins are hybrids between receptors and effectors: they are receptor channels. To this group belongs the nicotinic acetylcholine receptor which functions as a channel for monovalent cations (Changeux et al., 1984). We also include in this group the receptor for inositol trisphosphate because it is a $\mathrm{Ca}^{2+}$ channel in the endoplasmic reticulum. In this case, the ligand is not a hormone or neurotransmitter but a second messenger (Berridge and Irvine, 1989). Studies from several laboratories (Supattapone et al,, 1988; Ferris et al., 1989; Furuichi et al., 1989) have indicated that the structure of the inositol trisphosphate receptor is strikingly similar to the recently cloned $\mathrm{Ca}^{2+}$ channel of the sarcoplasmic reticulum of skeletal muscle which binds ryonidine. This was recently discussed by Gill (1989). From hydrophobicity profiles, it was concluded that the protein may contain between seven and nine membrane-spanning domains. The cDNA-derived $M_{\mathrm{r}}$ is 313000 but the $M_{\mathrm{r}}$ of the solubilized protein is around $10^{6}$, suggesting a tetrameric structure. Cooperativity of inositol trisphosphate binding is in accordance with an oligomeric structure. In a model, it is assumed that four subunits surround a central $\mathrm{Ca}^{2+}$ channel. 


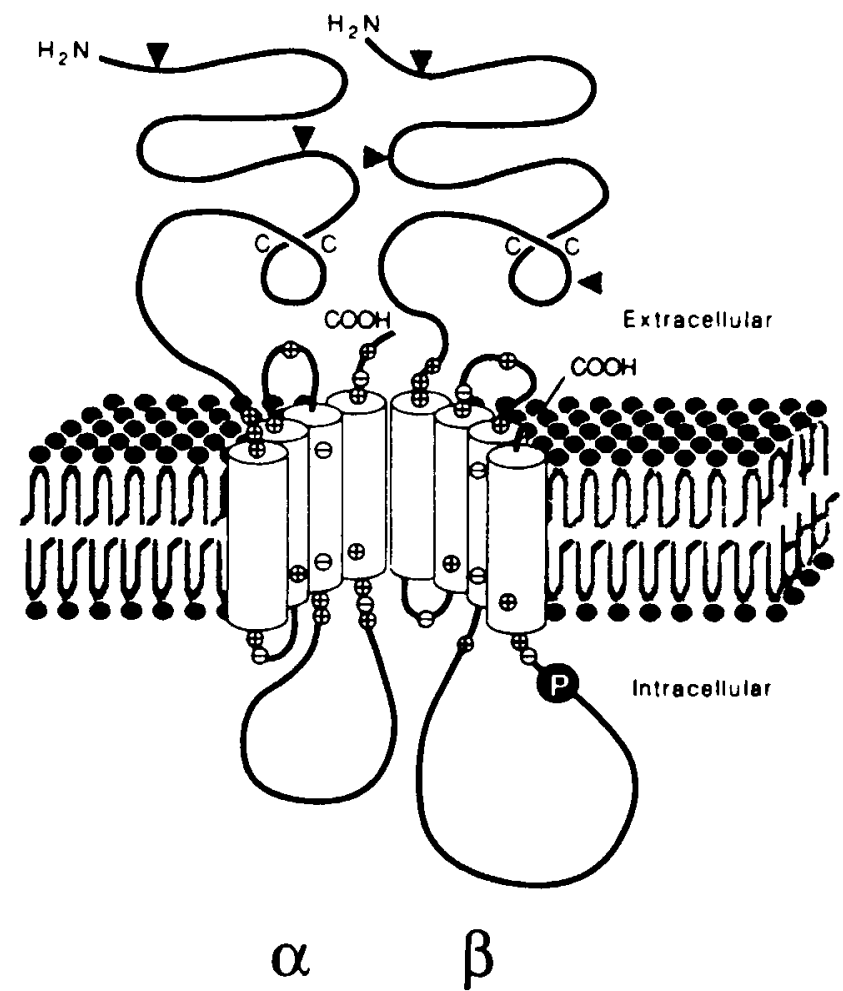

Fig. 4. Hypothetical membrane topology of the GABA receptor from bovine cerebral cortex. [Reproduced from Schofield et al. (1987) with permission of the author and Nature.] This schematic model is representative for a receptor family to which also the nicotinic acetylcholine and the glycine receptors belong. The cylinders represent four membrane-spanning helices in each subunit. It is assumed that two copies of each of the subunits are present in the $\alpha$-and $\beta$-receptor complexes. The charged residues $(\oplus, \ominus)$ are indicated. The site for cAMP-dependent serine phosphorylation in the $\beta$-subunit is marked (P) and the extracellular sites for $N$-glycosylation are indicated by $(\boldsymbol{\nabla})$

In cases where a receptor has an oligomeric structure, as exemplified by the nicotinic acetylcholine receptor $\left(\alpha_{2} \beta \gamma \delta\right)$, the possibilities for structural heterogeneity will become even more numerous. When, for example, subtypes of each monomer exist, a large number of variations is possible in the arrangement of oligomers. An impressive recent example of that kind of structural variability is the $\mathrm{GABA}_{\mathrm{A}}$ receptor which is also a chloride channel (Schofield et al., 1987; see Fig. 4). This receptor binds the inhibitory neurotransmitter $\gamma$ aminobutyric acid (GABA). It is a hetero-oligomeric protein made up from subunits of which each contains four membrane-spanning helices. The polypeptides have only $20-40 \%$ identity with each other and $10-20 \%$ identity with the polypeptides of the $\mathrm{nAcCh}$ receptor and of the strychnine-sensitive glycine receptor. Since each polypeptide is coded by several genes, a number of heterogenous forms with $60-80 \%$ sequence similarity may be expressed. Different subtypes, then, give rise to a variety of different oligomeric isoforms with different pharmacological sensitivities. On the other hand, heterogeneity resulting from variations in the level of expression and post-translational modification may be responsible for regional differences in the function of $\mathrm{GABA}_{\mathrm{A}}$ receptors in the brain (Olsen and Tobin 1990).

Among the dozens of receptors which couple with Gproteins and activate adenylate cyclase, both $\beta_{1}$ - and $\beta_{2^{-}}$ adrenoceptors have been cloned and purified to homogeneity (for the original literature see Lefkowitz and Caron, 1988) and reconstituted functionally in lipid vesicles together with purified G-proteins and the target enzyme, adenylate cyclase (May et al., 1985; Feder et al., 1986). Actually, $\beta$-adrenergic activation of adenylate cyclase is the signal transmission pathway which, together with visual signal transmission in the retina, has been studied in greatest detail (for reviews see Lefkowitz and Caron, 1988; Levitzki, 1988; Pfeuffer and Helmreich, 1988).

Catecholamines, adrenaline, noradrenaline and many synthetic adrenergic agonists, partial agonists and blockers bind to adrenoceptors. Analysis at the level of the gene has identified the structural domains involved in ligand binding. The replacement of single highly conserved cysteinyl residues either in a transmembrane domain or in a cytoplasmic domain led either to an unchanged or an increased ligand affinity but in each case resulted in a significant impairment of the receptor's capacity to stimulate adenylate cyclase (Fraser, 1989; O'Dowd et al., 1989; Hausdorff et al., 1990b). In support of the importance of cysteinyl residues in $\beta$-adrenoceptor function are recent data on a role of disulfide bridges in forming the ligand binding site of the $\beta_{2}$-adrenergic receptor (Dohlman et al., 1990). The use of site-directed mutagenesis helped to clarify the involvement of disulfide bonds in ligand binding to the $\beta$-receptor; the evidence presented in previous studies gave equivocal results because they were carried out with crude receptor preparations or membranes and with reducing agents, dithiothreitol, or sulfhydryl-specific agents, such as $N$-ethylmaleimide, so that effects on other components of the adenylate cyclase system could not be excluded (see Vauquelin et al., 1979; Heidenreich et al., 1982; Korner et al., 1982). Therefore, sulfhydryl-disulfide interchange may also play a role in the activation of $\beta$-adrenoceptors (Moxham et al., 1988) as it does in the case of insulin receptors (cf. Olson and Lane, 1989; see also Fig. 5).

Various $\beta$-adrenergic agonists differ in affinity to $\beta$ adrenoceptors but increased efficacy is not necessarily associated with increased affinity (Eimerl et al., 1987). Moreover, one and the same ligand can act as antagonist, partial agonist or full agonist depending on the cellular medium, as shown with CGP 12177, a hydrophilic $\beta$-adrenergic ligand originally thought to be an antagonist (Staehelin et al., 1983; Portenier et al., 1984; Mohell and Dicker, 1989). Finally it must be said that the influence of the membraneous environment on the efficacy of hormones and agonists has been neglected. But as long as the molecular mechanisms of receptor activation are unknown, it will remain difficult to explain functional heterogeneity of receptors as a result of environmental effects, as exemplified by the case of vasoconstrictive $\alpha_{1}$-adrenoceptors which vary in different tissues and in different animal species in ligand affinity and biological activity (Bevan et al., 1989). What applies to $\beta$-adrenoceptor activation also applies to desensitization (Hausdorff et al., 1990a; see Fig. 5). Therefore, at present the non-responsiveness of receptors to agonists can only be described phenomenologically, since information on the nature of structural transitions accompanying activation and deactivation is not yet available. As an example, the phenomenon of hysteretic behavior in response to agonist binding to the $\mathrm{nAcChR}$ will be described.

\section{Receptor desensitization and membrane transduction hysteresis}

In the case of enzymes, kinetic delay phenomena, resulting from binding of substrate or other kinds of ligands, are sometimes denoted as hysteretic behaviour (Frieden, 1971). This concept was applied to adenylate cyclase and the activation 


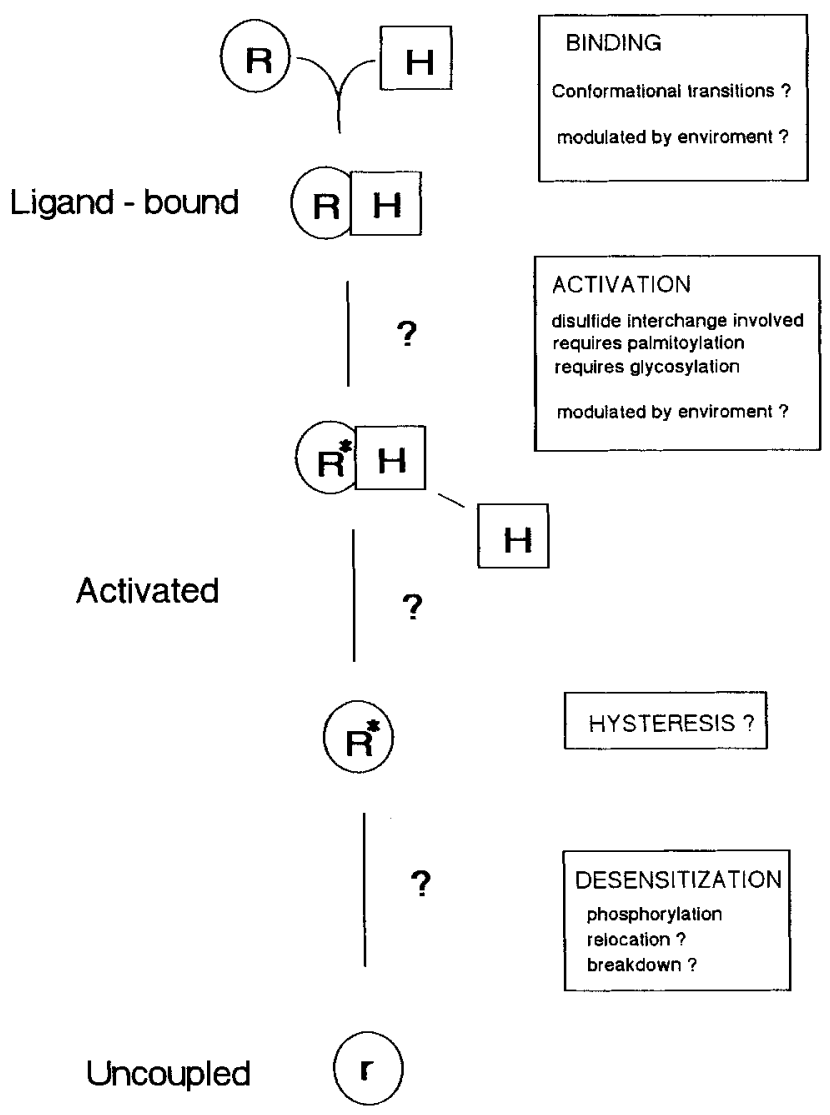

Fig. 5. Events in activation and desensitization of $\beta$-adrenoceptor function

of $\mathrm{G}_{\mathrm{s}}$ by $\mathrm{Mg}^{2+}$ ions (Iyengar, 1981). In the case of the $\mathrm{nAcChR}$ of Torpedo californica electrocytes, an extremely stable hysteresis loop exists in neurotransmitter binding due to a concentration-dilution cycle for the agonist (Chang et al., 1984). Antagonists, on the other hand, show conventional equilibrium binding, but no hysteresis. The structural hysteresis with respect to acetylcholine $(\mathrm{AcCh})$ binding was interpreted in terms of extremely long-lived metastable conformations of the receptor homodimer species $\left(M_{\mathbf{r}} 580000\right)$. Phenomenologically, the main hysteresis loop has internal smaller scanning loops (Fig. 6) and therefore, at a given AcCh concentration, the main loop can be transversed from the lower to the upper branch, for example on dialysis (Neumann et al., 1988). Hysteresis is not only an indication for structural cooperativity in non-equilibrium states, but a hysteresis loop is also a physical memory device. Furthermore, hysteresis can be a mechanism leading to chemical oscillations. Along these lines the scanning curves of the $\mathrm{nAcChR}$ system can, in principle, function as a multidomain memory system (Neumann, 1973).

AcChR hysteresis and receptor desensitization appear to be intimately related, because hysteresis is observed in a concentration range where the receptor becomes desensitized. The receptor can exist in various interconvertible conformational states: $\mathrm{R}_{\mathrm{h}}$ (high AcCh binding affinity, $K_{\mathrm{h}} \approx 10^{-7} \mathrm{M}$ ), $\mathrm{R}_{\mathrm{vh}}$ (very high AcCh binding affinity, $K_{\mathrm{vh}} \leq 10^{-9} \mathrm{M}$ ) (see Fig. 7), and a low-affinity state, $\mathrm{R}_{1},\left(\bar{K}_{1} \approx 10^{-4} \mathrm{M}\right)$ which is the channel-active state. Accordingly, the capability of a protein to form long-lived metastable states with hysteretic properties is thought to allow a receptor to dampen activation and maintain an inactive state. Hysteretic behaviour in activator binding qualifies a receptor as a structure which recalls previous

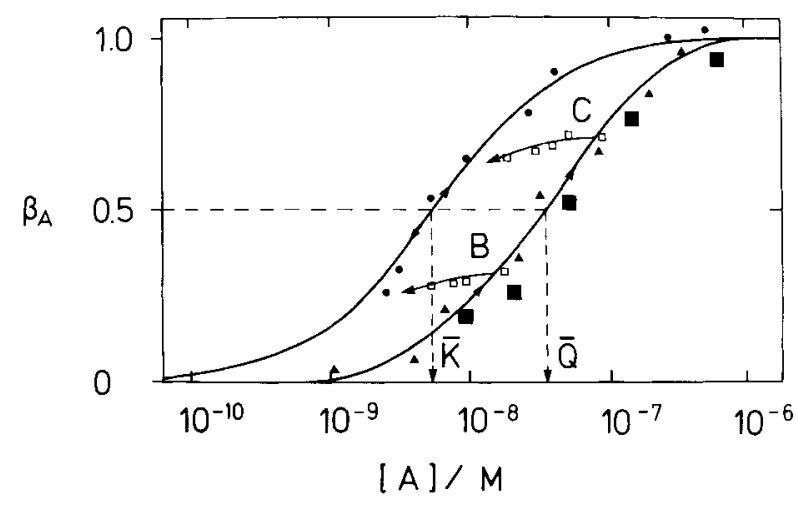

Fig. 6. Hysteresis loop of acetylcholine $(A)$, binding to Torpedo californica nicotinic acetylcholine receptor ( $n A C C h R$ ) in membranes. On the ordinate, $\beta_{\mathrm{A}}$ is the degree of binding of AcCh. At equilibrium, $\beta_{\mathrm{A}}=[\mathrm{A}] /([\mathrm{A}]+K)$, where $K$ is the overall equilibrium constant $(5 \pm 2 \mathrm{nM})$. On the abscissa is given the molar concentration of free A. (A) The lower branch of the hysteresis loop was obtained after a pulse-like addition of $\mathrm{A}$; (-) the upper branch was obtained after equilibrium dialysis for $22 \mathrm{~h}$ at $4{ }^{\circ} \mathrm{C}$; it therefore represents the equilibrium binding curve with $K=5( \pm 2) \mathrm{nM}$, whereas the lower branch represents a distribution of long-lived metastable receptor conformers (see text). Dilution scans ( $\square$ ) are shown starting at B and C from the lower hysteresis branch represented by $\bar{Q}$, the half-saturation value which was $0.04( \pm 0.02) \mu \mathrm{M}$ at $4^{\circ} \mathrm{C}$. The receptor concentration based on $M_{\mathrm{r}}=290000$ was always $1 \mu \mathrm{M}$. ( $\left.\boldsymbol{\square}\right)$ Data points from experiments where the phosphatidylinositol-4-kinase activity of the isolated, purified receptor was measured as a function of [A]. For further details see Neumann et al. (1988) and text

encounters with an agonist. For example, a small degree of binding is indicative for a pulse-like exposure to the agonist, whereas a high degree of binding points to a slow, leak-like exposure of low, diluted concentrations of $\mathrm{AcCh}$ to the receptor.

It is commonly assumed that a desensitized receptor has lost its function. But recent evidence suggests that a desensitized $\mathrm{nAcChR}$ may not be completely nonfunctional; a desensitized receptor may no longer be capable of activating the primary response characteristic for the hormone or transmitter to which it binds, but it may still be capable of activating a secondary pathway more slowly. This was shown to be the case with the desensitized nAcChR of Torpedo. Both AcCh monomers and dimers, although the latter to a much greater extent, were found to catalyze the formation of phosphatidylinositol 4-phosphate (PtdIns4P) from receptorassociated phosphatidyl-inositol (PtdIns) and $\mathrm{Mg}^{2+}$-ATP and also its hydrolysis (Kiehl et al., 1987; Herlemann, 1989). This catalytic activity of the Torpedo $\mathrm{nAcChR}$ is expressed in the same concentration range of $\mathrm{AcCh}$ in which channel-desensitization of the receptor occurs. A similar situation, that is a dual function of a receptor, was recently encountered in the case of glucagon and prostaglandin $E_{1}$-receptors on MDCK cells (Kurstjens et al., 1990a). Another interesting example is the stimulation of phospholipase $\mathrm{C}$ by $(\mathrm{P})$ ligands in turkey erythrocyte membranes which was dependent on guanosine 5'-O-(3-thiotriphosphate) (GTP $[\gamma \mathrm{S}]$ ) like the G-protein-dependent activation of adenylate cyclase in these cells (Boyer et al., 1989). In this case, the activation by GTP analoga was delayed, pointing to a kinetically 'hysteretic' activation.

It should be noted that the PtdIns kinase activity of the Torpedo $\mathrm{nAcChR}$ in response to $\mathrm{AcCh}$ increased along the lower branch of the hysteresis loop (cf. Fig. 6). Since the extent of expression of the PtdIns kinase and PtdIns4P hydrolase 


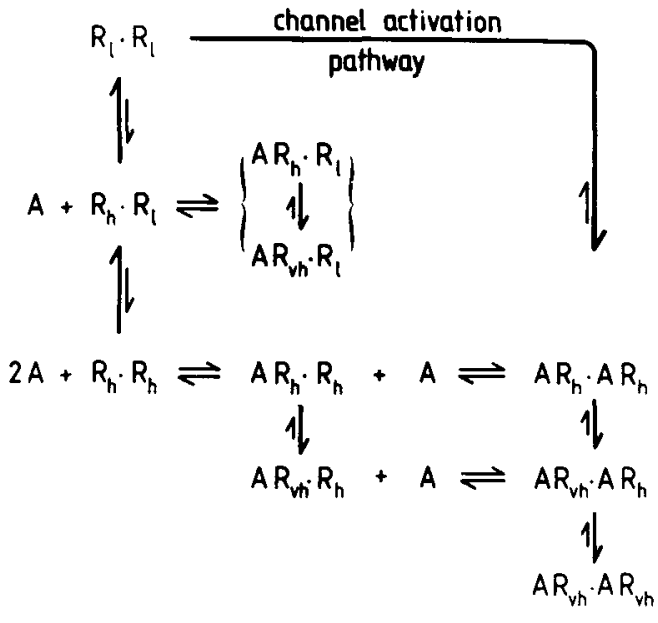

Fig. 7. Scheme for the hysteresis of acetylcholine (A) binding to the $\mathrm{T}$. californica nicotinic acetylcholine receptor ( $A A C C h R)$. [Reproduced from Neumann et al. (1988).] Bimolecular binding steps are aligned horizontally, whereas vertical steps are the slow structural isomerizations. $R_{\mathbf{J}}$ is the low-affinity form of the receptor with $\bar{K}_{1} \approx 100 \mu \mathrm{M} ; \mathrm{R}_{\mathrm{h}}$ is the high-affinity conformer with $K_{\mathrm{h}} \approx 0.1 \mu \mathrm{M}$ and $\mathrm{R}_{\mathrm{vh}}$ is the very high-affinity conformer with $K_{\mathrm{vh}} \leq 5( \pm 2) \mathrm{nM}$. The $R_{h} \cdot R_{1}$ hybrid is a branch point from where $R_{v h} \cdot R_{1}$ may form as dead-end product when pulses of $\mathrm{A}$ are applied giving rise to nonequilibrium states. The preferred direction of the isomerization equilibria is indicated by the thicker arrows. The long upper arrow indicates the channel activation pathway. At high $[\mathrm{A}](>10 \mu \mathrm{M})$, the low-affinity conformer $R_{1}$ is the major binding species which is responsible for channel opening. With prolonged exposure to $\mathrm{AcCh}$, $R$, the receptor, is finally transformed into the high-affinity conformers, $R_{h}$ and $R_{v h}$. At low $[A](<10 \mu M)$, the $R_{h}$ conformer is the predominant binding partner for $\mathrm{AcCh}$ and is on the direct route to the final complex $A \cdot R_{\mathrm{vh}}$. 'Single-pulse mode addition' of A favours formation of the hybrid binding state $A \cdot R_{v h} \cdot R_{1}$ which is a kind of dead-end state and can only be reversed when $[\mathrm{A}]$ becomes $>1 \mu \mathrm{M}$. 'Dialysis mode addition', i.e. equilibrium binding, ultimately leads to the dimeric $A \cdot R_{v h} \cdot A \cdot R_{v h}$ conformer complexes (see Fig. 6 and text). For further information Neumann et al. (1988) should be consulted

activities is tightly coupled to AcCh binding, it is very likely that the AcCh binding hysteresis leads to a hysteresis of the receptor-mediated PtdIns phosphorylation - dephosphorylation (see Carpenter and Cantley, 1990). Consequently, an event on the cell surface, such as hysteretic AcCh binding to the nAcCh receptor, i.e. with memory of the encounter, can be transduced across the membrane to the PtdIns pathway which, as a consequence, gains hysteretic properties and thus molecular memory. In summary (Fig. 7), AcCh binding is not only responsible for the hysteretic behaviour of the channel desensitization in the classical synaptic transmission, but may also cause a hysteretic modulation of the PtdIns pathway. Various subtypes of the $\mathrm{nAcChR}$ appear to differ in their channel functions in response to agonists and antagonists, but information is not yet available to what extent hysteretic transmitter binding and its consequences for desensitization differ among these isoforms.

Returning to G-coupled hormone receptors, it is of course tempting to speculate that the high-and low-affinity states described by Lefkowitz and his coworkers (Stiles et al., 1984) for the $\beta$-adrenoceptor are indicative of metastable conformers. However, this cannot be decided on the basis of differences in affinity alone because different affinity states are necessary but insufficient criteria for metastability and hysteresis. But it would certainly be interesting to learn whether other transmitter and hormone receptors have hysteretic properties like the Torpedo AcChR.

Along the same line, it must be admitted that, based on presently available information and considering the bewildering variety of post-translational epigenetic modifications of the $\beta$-adrenoceptor, the G-proteins and adenylate cyclase, it is difficult to assign a clear and unequivocal functional or structural role to each of these structural changes (see Fig. 5). The modifications of protein components of signal transmission chains include, besides familiar modifications, such as glycosylation, phosphorylation, ADP-ribosylation, also myristoylation, isoprenylation and carboxymethylation (see Yamane et al., 1990; Fung et al., 1990; James and Olson, 1990; Jones et al., 1990; Maltese and Robishaw, 1990; Mumby et al., $1990 \mathrm{a}, \mathrm{b}$ ). Special attention was given to the role of phosphorylation of the $\beta$-adrenoceptor in homologous desensitization (Hausdorff et al., 1990a). However, an inclusion of post-translational modifications in a discussion of structural and functional heterogeneity of receptors and G-proteins, even in a cursory manner, would go far beyond the scope of this review.

The conformational transition due to the interaction of agonist with receptor is responsible for the formation of the active GTP-binding form of the G-protein. The activated receptor acts as exchanger (Allende, 1988), promoting the discharge of GDP from the G-protein and the binding of GTP. But once the active GTP-binding form has been produced, the hormone-receptor complex is no longer required because the next step, namely the activation (or inhibition) of the target, is solely a matter to be decided by the target and its complementary activated G-protein (for a review see Pfeuffer and Helmreich, 1988; Birnbaumer et al., 1990). Thus, each G-protein-linked receptor must have domains to which the coupling partners can bind. Structural heterogeneity of the receptor is therefore only one side of the coin. In order to complete the picture, receptor heterogeneity must be discussed in conjunction with the structural properties of the coupling partners, the G-proteins.

\section{Structural properties of G-proteins}

The structural diversity is equally impressive in the case of G-proteins. GTP-binding proteins participating in hormonal signal transfer are heterotrimers with the structure $\alpha\left(M_{\mathrm{r}}\right.$ $39000-46000), \beta\left(M_{\mathrm{r}} 35000-36000\right.$ and 37000$)$ and $\gamma\left(M_{\mathrm{r}}\right.$ $8000-10000$ ). Only the $\alpha$-subunits bind and hydrolyze GTP to GDP and $P_{i}$ and are ADP-ribosylated by cholera toxin $\left(G_{1}\right.$ and $\left.G_{s}\right)$ or by pertussis toxin $\left(G_{t}, G_{0}, G_{i}\right)$. The more hydrophilic $\alpha$-subunits of $G_{0}, G_{i}, G_{t}$ and $G_{z}$ but not of $G_{s}$ are also $N$-myristoylated (Jones et al., 1990; Mumby et al., 1990a).

Thanks to recombinant DNA technology, nine genes and $15 \mathrm{G} \alpha$-subunits, which are products of these genes, have been identified so far (Harris et al., 1985; Bray et al., 1986; Itoh et al., 1986; Mattera et al., 1986; Nukada et al., 1986a, b; Robishaw et al., 1986a, b; Sullivan et al., 1986; Jones and Reed, 1987). But, this list is far from complete and additional subunits are being discovered continually. Four different $\alpha$ subunits of $G_{s}$ and two out of four different $\alpha$-subunits of $G_{o}$ are formed by alternative splicing (Itoh et al., 1986; Jones and Reed, 1987; Kozasa et al., 1988; Bertrand et al., 1990).

How this structural heterogeneity is related to functional diversity is not yet clear. For example, $\mathrm{G}_{\mathrm{s}}$ activates adenylate cyclase but also dihydropyridine-sensitive $\mathrm{Ca}^{2+}$ channels (Yatani et al., 1987b; Brown and Birnbaumer, 1988; Mattera 
Table 1. Function of $G$-proteins in signal transduction

For literature consult Bray et al. (1986); Nukada et al. (1986a, b); Robishaw et al. (1986a, b); Stryer (1986); Barbacid (1987); Gilman (1987); Hescheler et al. (1987); Jones and Reed (1987, 1989); Schultz and Rosenthal (1987); Yatani et al. (1987a, b, 1988); Brown and Birnbaumer (1988); Fong et al. (1988); Itoh et al. (1988); Kozasa et al. (1988); Lochrie and Simon (1988); Matsuoka et al. (1988); Nakajima et al. (1988); Pfeuffer and Helmreich (1988); VanDongen et al. (1988); Freissmuth et al. (1989); Gilman (1989); Graziano et al. (1989); Mattera et al. (1989); Bertrand et al. (1990); Birnbaumer et al. (1990); Inanobe et al. (1990); Pang and Sternweis (1990); Price et al. (1990); Shinjo et al. (1990). See references in the text, especially for ras proteins. Please consult the text for further examples

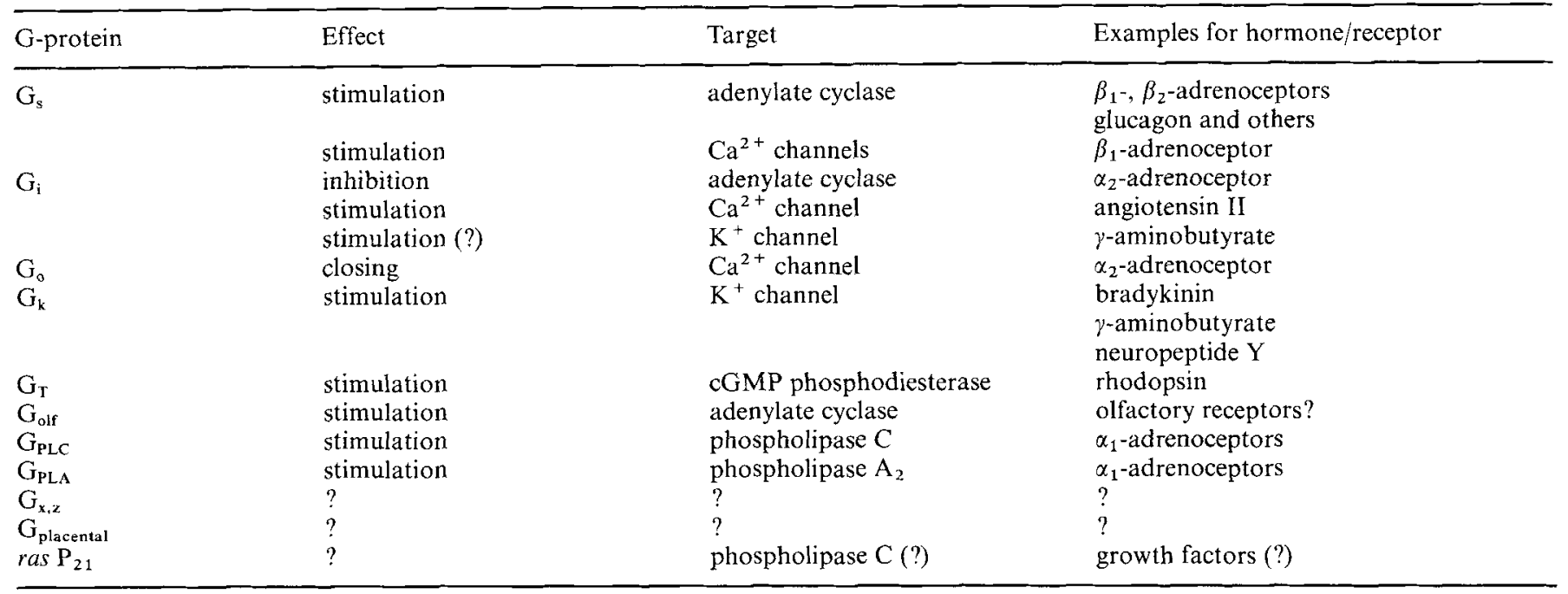

et al., 1989) and a pertussis-toxin-sensitive $G_{\mathbf{k}}$ from human red blood cells activates a $\mathrm{K}^{+}$channel (see Table 1). Bourne and his colleagues have found a mutated $G_{s \alpha}$ with a deleted Arg201 in tumours of the hypophysis with an accelerated rate of production of growth hormone and increased cellular cAMP levels (Landis et al., 1989). The same amino acid side chain is ADP-ribosylated in normal $G_{5 \alpha}$ by cholera toxin. Accordingly, the GTPase of this mutant $\mathrm{G}_{\mathrm{s} \alpha}$ was blocked like that in normal ADP-ribosylated $\mathrm{G}_{s \alpha}$, which explains the adenylate cyclase activation and the elevated cAMP levels. There are also two isoforms of the retinal G-protein, transducin, $G_{t}$, which link rhodopsin to the cGMP-specific phosphodiesterase. These isoforms are apparently expressed exclusively in retinal rods and cones, respectively (Lochrie et al., 1985; Medynski et al., 1985; Tanabe et al., 1985; Yatsunami and Khorana, 1985; Lerea et al., 1986).

$\mathrm{G}_{\mathbf{i}}$ was originally thought to be involved primarily in adenylate cyclase inhibition by inhibitory receptors, such as $\alpha_{2}$-adrenoceptors. Up to now, at least three different $\alpha_{i}$-subunits are known (Itoh et al., 1986, 1988; Nukada et al., 1986 b; Sullivan et al., 1986; Bray et al., 1987). They were named $\alpha_{i}$ $1, \alpha_{i}-2, \alpha_{i}-3$, on the basis of the order in which they were cloned (cf. Suki et al., 1987). They seem to be involved, as exemplified by the $\alpha$-subunit of $G_{i}-3, G_{k}$, which opens atrial $K^{+}$-channels (cf. Codina et al., 1987) in a variety of separate functions which are lumped together as pertussis-toxin-sensitive events (Schultz and Rosenthal, 1987; VanDongen et al., 1988; Yatani et al., 1988a). Some of these effects, for example regulation of cation channels, might turn out to be biologically as important or more important as adenylate cyclase inhibition.

One of the more abundant $\mathrm{G}$-proteins is $\mathrm{G}_{\mathrm{o}}$ which is mainly found in brain where it amounts to $1 \%$ of all membrane proteins. There are at least four different $G_{0 \alpha}$-subunits (Inanobe et al., 1990). $G_{0}$, like $G_{i}$, can be linked to muscarinic acetylcholine receptors, $\alpha_{2}$-adrenoceptors, to rhodopsin and also to $\beta_{1}$-adrenoceptors (see Kurstjens et al., 1991). The pertussis-toxin-sensitive events in which $G_{0}$ is involved are, like those in the case of $G_{i}$, not yet fully understood. Thus, $G_{i}$ and $\mathrm{G}_{\mathbf{0}}$ have been assumed to play a role in the regulation of $\mathrm{K}^{+}$and neuronal $\mathrm{Ca}^{2+}$ channels and in the coupling of the latter to the neuropeptide $\mathrm{Y}$ receptor and of the $\mathrm{Na}^{+}-\mathrm{H}^{+}$ antiporter (Hescheler et al., 1987; Yatani et al., 1987a, b; Ewald et al., 1988). An involvement of a pertussis-toxin-sensitive $\mathrm{G}$-protein in the activation of phospholipase $\mathrm{C}$, which leads to the formation of inositol trisphosphate and to the release of intracellular $\mathrm{Ca}^{2+}$, has been much discussed, but this G-protein has not yet been identified (Fain et al., 1988).

$G_{0}$ has recently been shown to be a major component of the neuronal growth cone membrane and to interact with GAP-43, which is a growth-associated protein with $M_{\mathrm{r}} 43000$ (Strittmatter et al., 1990). GAP-43 stimulated GTP $[\gamma$ S $]$-binding to $G_{0}$. GAP-43 is unique among regulators of heterotrimeric $G$-proteins in that it is an intracellular protein and has an overall structure which is quite different from that of the G-protein-coupled receptors.

Recently, a new G-protein, $G_{z}$ or $G_{x}$, has been cloned (Fong et al., 1988; Matsuoka et al., 1988). It resembles $G_{i \alpha}$ and $G_{\alpha \alpha}$ but with two notable differences: three amino acid residues in the first portion of the guanine-nucleotide-binding domain, which are strictly conserved in all other known $\alpha$ subunits and which are assumed to be involved in the GTPase activity, are different. This leads apparently to drastically altered kinetics for the GTPase reaction of $\mathrm{G}_{z \alpha}$ (cf. Gilman, 1989). The other difference is the absence of the cysteine residue near the carboxyl terminus which is the site for pertussis-toxin-catalyzed ADP-ribosylation. Hence, $\mathrm{G}_{z}$ could be responsible for GTP-dependent but pertussis-toxin-insensitive events. In some cells receptor-mediated regulation of phospholipase $C$ activity might be such a pathway. $G_{z}$ might also have a function in the regulation of ion channels. For example, substance $P$ is known to inhibit an outward rectifying potassium current in cultured brain neurons in a pertussistoxin-insensitive but GTP-dependent fashion (Nakajima et al., 1988). $G_{z}$ might participate in this pathway.

Other new G-proteins which are not ADP-ribosylated by pertussis toxin have come to light recently (Pang and 
Sternweis, 1990). Moreover, olfactory neuron-specific G-proteins have been cloned (Jones and Reed, 1989). The latter have apparently a function in odorant signal transduction, although the odorant receptors have not yet been identified. Structurally similar G-proteins were also found in Drosophila (Provost et al., 1988), in yeast (Dietzel and Kurjan, 1987; Nakafuku et al., 1987, 1988) and in Dictyostelium (Pupillo et al., 1989) where they participate in regulation of adenylate cyclase activity and are involved in the function of mating factors in yeast.

Other genes encode closely related but distinct $\beta$-subunits: the $\beta$-subunit of transducin is a protein with $M_{\mathrm{r}} 36000$ (Amatruda et al., 1988), whereas the other G-proteins contain a doublet made up from a $\beta_{1}$-protein with $M_{\mathrm{r}} 36000$ and a $\beta_{2}$-protein with $M_{\mathrm{r}} 35000$ (Sugimoto et al., 1985; Evans et al., 1987; Fong et al., 1987; Gao et al., 1987). Recently a third $\left(\beta_{3}\right)$ form of the $\beta$-subunit was detected by screening bovine and human retina cDNA libraries. The encoded peptide with $M_{\mathrm{r}} 37000$ is $83 \%$ identical with the $\beta_{1}$ form and $81 \%$ identical with the $\beta_{2}$ form (Levine et al., 1990).

A great variability of the $\gamma$-subunits is now also becoming apparent: cDNAs encoding four structurally distinct $\gamma$-subunits have been identified. But the differences in the mobilities of $\gamma$-subunits of several G-proteins (Gautam et al., 1990) and the isolation of proteolytic fragments from bovine brain Gproteins with amino acid sequences that are distinct from but similar to $\gamma$-subunits suggest that unidentified members of the $\gamma$-subunit family still exist (Gautam et al., 1989, 1990; Robishaw et al., 1989).

Gautam et al. (1990) have recently probed the heterogeneity of $\gamma$-subunits from different tissues by cDNA synthesis using the polymerase chain reaction and immunoblot analysis using antibodies against synthetic peptides. Based on the pattern of tissue-specific expression, $\gamma$-subunits were divided into three classes: $\gamma_{2}$ which is ubiquitous; $\gamma_{3}$ which is tissue-specific and $\gamma_{1}$ which is cell-type-specific. There is evidence to support this notion because transducin from rod outer segments of the bovine eye, which has only one form of the $\beta$-subunit $\left(\beta_{1}\right)$ (Amatruda et al., 1988), also has only one form of the $\gamma$ subunit $\left(\gamma_{1}\right)$ (Gautam et al., 1990). Thus the $\gamma$-subunit of transducin and that of the G-proteins in brain which have been cloned and of which there are at least two types, are different. Moreover, the $\gamma$-subunits associated with $G_{s}, G_{i}$ and $G_{0}$ from bovine brain also appear to be distinct species (Robishaw et al., 1989).

A function for $(\beta) \gamma$-subunits in anchoring $\alpha$-subunits to the membrane (Sternweis, 1986) is supported by the recent finding that the $\gamma$-subunit of brain G-proteins is carboxymethylated or isoprenylated at a C-terminal cysteine (Fung et al., 1990; Maltese and Robishaw, 1990; Mumby et al., 1990b). As important might be a function of $(\beta) \gamma$-subunits in anchoring $\alpha$-subunits to the receptor (Kurstjens et al., 1991). Based on the assumption that $\beta \gamma$-subunits are anchoring $\alpha$-subunits to receptors, one might speculate that the diversity of $\gamma$ - (and $\beta$-) subunits is partly responsible for enlarging the repertoire for interactions of $\alpha$-subunits with receptors (Fig. $1 \mathrm{~A}$ and C; see also Gautam et al., 1990). But up to now there is no information available regarding the specificity of binding of $\beta \gamma$-subunits to receptors.

Bourne et al. (1990) in a recent review have stated the prevailing notion, namely 'that $\beta \gamma$-subunits are believed to be involved in binding of $\alpha$-subunits to the receptor and in increasing $K_{\mathrm{d}}$ for GDP but that they are not thought to have a direct role in discriminating between different receptor subtypes'. The latter is the crucial point because if the $(\beta) \gamma$-sub- unit, apart from the $\alpha$-subunit, could also determine the specificity of interaction of G-proteins with the receptor, this could be a device to link many more receptors, of which more than a hundred may exist, to G-protein-coupled signal transmission pathways. This suggestion has lately received some support from experiments with preparations of sealed unilamellar lipid vesicles which can be separated according to their size and density by sucrose gradient centrifugation. When separate $\alpha_{0}$ subunits were reconstituted with the $\beta_{1}$-adrenoceptor some of them were recovered in the heavier vesicle fraction containing the receptor. But much more $\alpha_{0}$ was bound in the presence of $\beta \gamma$-subunits suggesting a cooperative anchoring function of receptor-bound $\beta \gamma$-subunits for $\alpha$-subunits (Kurstjens et al., 1991).

One must be aware that these are qualitative data. Unfortunately, it has not yet been possible to assess the individual contributions of $\beta$ - and $\gamma$-subunits to the interaction with $\alpha$ subunits of $\mathrm{G}_{\mathrm{s}}$ and to the interactions of the latter with receptors, because the $\beta$ - and $\gamma$-polypeptides can only be separated under denaturing conditions and separate (native) $\alpha_{\mathrm{s}}$-subunits are not yet available (cf. Graziano et al., 1989). This will eventually be overcome by producing functional separate $\alpha$, $\beta$ - and $\gamma$-subunits with the aid of suitable gene expression systems.

Therefore, whereas in the past the role of $\alpha$-subunits was in the center of attention, it is now the role of the $\beta$ - and $\gamma$ subunits. They are interchangeable among the $\alpha$-subunits of the nonretinal $G$-proteins, $G_{s}, G_{i}, G_{o}$, but $G_{s}$ can discriminate between transducin $\beta \gamma$, and the $\beta \gamma$ complex resolved from the nonretinal G-proteins of the brain (Hekman et al., 1987; Casey et al., 1989). However, quantitative information is lacking. Moreover, the $\beta \gamma$-complex alone attaches to the receptor (Im et al., 1988; Kurstjens et al., 1991) and appears to be part of the recognition site for G-protein $-\alpha$-subunits. $\beta \gamma$-Subunits also contribute in a concentration-dependent manner both to the hormonal activation and to the deactivation of $\mathrm{G}_{\mathrm{s} \alpha}$ (Hekman et al., 1987).

Whether $\beta \gamma$-subunits can interact directly or indirectly with target enzymes, such as adenylate cyclase and other effectors, in a functionally relevant manner remains open (Katada et al., 1986; Marbach et al., 1990). In this context it may be mentioned briefly that a controversy concerning the role of $\alpha$ or $\beta \gamma$-subunits of $\mathrm{G}_{\mathrm{i}}-3$ (or $\mathrm{G}_{\mathrm{k}}$ ) in the regulation of muscarinic acetylcholine receptor-gated $\mathrm{K}^{+}$channels has received much attention. Whereas Logothetis et al. $(1987,1988)$ have reported that $\beta \gamma$-subunits from brain and human placenta stimulate $\mathrm{K}^{+}$channels in guinea-pig atrial cells, Birnbaumer and coworkers (for more information see Brown and Birnbaumer, 1988; Birnbaumer et al., 1990) have consistently observed that $\mathrm{G}_{\mathrm{i} \alpha}$-subunits stimulate $\mathrm{K}^{+}$channels. The possibilities that these discrepancies are due to experimental variations in reagents and detergents or are a consequence of the heterogeneity of the preparations used has not yet been excluded. $\beta \gamma$ Subunits have also been implicated in the activation of cardiac phospholipase $\mathrm{A}_{2}$ (Axelrod et al., 1988) and it was speculated that the release of arachidonic acid as a consequence of the activation, is indirectly responsible for the activation of the $\mathrm{K}^{+}$-channels (Kim et al., 1989).

A special case among GTP-binding proteins is the large and still expanding family of small GTP-binding proteins. Some 30 mammalian proteins of this type and several different subfamilies have by now been identified. Members of this family are composed of a single GTP-binding ( $\alpha$ )-subunit with $M_{\mathrm{r}}$ ranging between $\approx 20000-30000$. They are either isoprenylated or palmitoylated or both (James and Olson, 
1990). Usually, the small GTP-binding proteins do not serve as substrates for ADP-ribosylation by bacterial toxins, nor do they form heterotrimers with $\beta \gamma$-subunits. There are exceptions in the case of the rho proteins (Yamamoto et al., 1988) and the closely related rac proteins which are substrates for the $\mathrm{C} 3$ exoenzyme of Clostridium botulinum (Aktories et al., 1987; Braun et al., 1989; Kikuchi et al., 1988). The modification results in a collapse of actin filaments, suggesting that rho proteins have a function in the cytoskeletal assembly of a cell (Rubin et al., 1988; Chardin et al., 1989). Wieland et al. (1990) have recently reported that rho $\mathrm{A}$ is a target for rhodopsin and that ADP-ribosylation by $\mathrm{C} 3$ is inhibited by light.

The function of the small G-proteins is understood in only a few cases: among these are the cytosolic ADP-ribosylation factor (ARF) which binds but does not hydrolyze GTP and which supports ADP-ribosylation by cholera toxin (Kahn and Gilman, 1986). This factor is apparently identical with the $A R F$ gene product (Stearns et al., 1990) and with two other small- $M_{\mathrm{r}}$ GTP-binding proteins in yeast which are products of the YPTI and SEC4 genes in Saccharomyces cerevisiae and which seem to be involved in the function of mating factors (Gallwitz et al., 1983; Salminen and Novick, 1987). The YPT1 and SEC4 gene products and other GTP-binding proteins in yeast, e.g. products of the $S A R I$ and $A R F$ genes and the rab and arf families of GTP-binding proteins in mammalian cells may have important roles in vectorial membrane traffic, in vesicular transport, exocytosis and membrane fusion and in the function of the Golgi (Melancon et al., 1987; Nakano and Muramatsu, 1989; Walworth et al., 1989; Chavrier et al., 1990; Stearns et al., 1990). In yeast a GTP-binding protein with $M_{\mathrm{r}} 21000$ is believed to be involved in endoplasmic reticulum Golgi protein transport (Nakano and Muramatsu, 1989; for reviews see Balch, 1990; Burgoyne, 1990; Gomperts, 1990; Rothman and Orci, 1990). An attractive candidate for such a role in mammalian cells is a small G-protein, named $\mathrm{rab} 3$, which is only found in synaptic vesicles in neurons and in vesicles of endocrine cells: rab 3 binds tightly to membranes and has only $30 \%$ sequence similarity with oncogenic ras proteins (Fischer v. Mollard et al., 1990).

The ras proteins are the most prominent members of this group. They are the products of the ras proto-oncogenes; one ras protein, $\mathrm{H}$-ras p 21 , was crystallized and its threedimensional structure resolved, first to about $0.25-\mathrm{nm}$ and subsequently to 0.135 -nm resolution (Pai et al., 1989, 1990). The ras proto-oncogene family codes for several small guanine-nucleotide-binding proteins with low intrinsic GTPase activities (for reviews see Barbacid, 1987; Burgoyne, 1989). Mutations inhibiting this activity produce a transforming protein, which suggests that ras proteins may play an important role in the control of cell proliferation, although their role in growthfactor-receptor-regulated signal transmission has remained elusive. Recently, an inhibition of coupling of muscarinic receptors to atrial $\mathrm{K}^{+}$-channels by ras p21 and GTPaseactivating protein, GAP, was reported (Yatani et al., 1990).

In the case of the large trimeric $\alpha \beta \gamma$-G-proteins in mammals, it is the hormone-activated receptor that functions as exchange factor, which promotes replacement of GDP by GTP. In Sacch. cerevisiae the product of the CDC25 gene appears to have a similar function (cf. Fischer v. Mollard et al., 1990). Another exchange factor increasing the off rate of GDP from the eukaryotic initiation factor, eIF2, is GEF (GDP-exchange factor), a large cytosolic multisubunit complex. The off rates for guanine nucleotides in the case of eIF2 are as slow as those of ras; it makes sense therefore that cytosolic factors exist that enhance hydrolysis of GTP by ras
(Vogel et al., 1988; for reviews see McCormick, 1989; Hall, 1990). Such a GAP-like protein was isolated from brain cytosol; it effectively catalyzed the release of bound GDP from ras in the presence of $\mathrm{Mg}^{2+}$. This protein was different from GAP and GEF (cf. Wolfman and Macara, 1990). Similar proteins seem to exist in yeast: these are the GAP homologues encoded by the IRAI and IRA2 genes (Ballester et al., 1989; Tanaka et al., 1989). Therefore, there may be as many GAP, GTPase-activating proteins, as GTP-binding proteins.

\section{Structural properties of adenylate cyclase and other target enzymes}

There are at least three, and most likely four, kinds of adenylate cyclase in mammalian cells: all are activated by Gproteins and one form is additionally regulated by calmodulin (Mollner and Pfeuffer, 1988). $\mathrm{Ca}^{2+}$-calmodulin sensitivity may be a special property of neural adenylate cyclases (Eliot et al., 1989). An immunologically different calmodulin-insensitive adenylate cyclase has been found in the olfactory epithelia of the rat (Pfeuffer et al., 1989). And recently, a new olfactory adenylate cyclase, termed type III, was cloned and expressed (Bakalyar and Reed, 1990).

It will be interesting to see how many isoforms of adenylate cyclase are expressed and whether differently regulated adenylate cyclases are found. A calmodulin-sensitive adenylate cyclase from bovine brain was cloned and sequenced (Krupinski et al., 1989). It was already known that adenylate cyclase is a glycoprotein like the adrenoceptor (Pfeuffer et al., 1985). Now it became apparent that adenylate cyclase, like the adrenoceptor and rhodopsin, has a large number (12) of hydrophobic transmembrane $\alpha$-helical segments.

Another remarkable feature is the similarity of the adenylate cyclase structure and that of $\mathrm{Ca}^{2+}$ and $\mathrm{K}^{+}$channels, and the so-called P-glycoprotein which is the product of the multidrug resistance gene (Gottesman and Pastan, 1988). The P-protein is responsible for the cellular export and the elimination of a number of chemical compounds and drugs. Accordingly, Gilman and colleagues (Krupinski et al., 1989), who have unravelled the structure, have suggested that mammalian adenylate cyclase may not only form but also export cAMP into the extracellular medium. A pathway which produces and secretes cAMP must exist in Dictyostelium discoideum (Devreotes, 1989) where cAMP actually serves as an extracellular signal for chemotaxis, cell adhesion and aggregation (cf. Klein et al., 1988).

A membrane-bound form of guanylate cyclase was likewise cloned and sequenced recently (Chinkers et al., 1989; for a review see Schulz et al., 1989). The guanylate cyclase belongs to a novel receptor family in which the binding of the agonist or hormone, for example of the atrial natriuretic peptide, initiates activation in one and the same peptide chain without involvement of other transducing elements. Guanylate cyclase is a double-headed receptor enzyme where the catalytic domain, which forms and releases cGMP, is oriented towards the cytosol.

We are aware that the list of target enzymes of G-proteindependent signal transmission chains is incomplete. For example, there is evidence of heterogeneity also in the case of phospholipase C. In fact, several species of phospholipase C have been purified and three different cDNAs were cloned (Katan et al., 1988; Suh et al., 1988). There are also several forms of cGMP phosphodiesterase linked to transducin (Hurwitz et al., 1984, 1985; Stryer, 1986; Beavo, 1988). There is little sequence similarity apparent between G-protein- 
coupled adenylate cyclase, phospholipase $C$ and cGMP phosphodiesterase. Thus, based on primary sequence, a common consensus domain in these target enzymes for $\mathrm{G}$-protein interactions cannot be made out. This points to the need for more information on a higher structural level.

\section{Implications of structural heterogeneity of receptors and G-proteins for multiple responses}

As is shown in Fig. $1 \mathrm{~A}$, originally it was believed that a variety of different receptors could be channeled via a common G-protein to their target or effector, for example adenylate cyclase. Families of stimulatory and inhibitory receptors were thought to regulate exclusively adenylate cyclase activity by means of stimulatory $\left(G_{s}\right)$ or inhibitory $\left(G_{i}\right)$ proteins. But it has become evident that $G$-proteins such as $G_{i}$ or $\mathrm{G}_{\mathrm{s}}$ have multiple functions and can interact with other targets besides adenylate cyclase, for example with cation channels (see Table 1).

The functional diversity raises the question of whether or not, for each of these separate functions, a separate, structurally distinct G-protein is required (see Fig. 1, B and C). There are many examples known of two or more distinct separate functions of one given hormone, even in one line of cells. For example, thrombin receptors in human platelets stimulate phospholipase C activity (Watson et al., 1984), but also inhibit adenylate cyclase (Jakobs et al., 1985; Katada et al., 1985). Other examples are vasopressin and angiotensin II receptors in liver (Pobiner et al., 1985; Uhing et al., 1986) and thyroidreleasing-hormone receptors in $\mathrm{GH}_{4} \mathrm{C}_{1}$ cells (Straub and Gershengorn, 1986). Moreover, it has been indicated that $\alpha_{2}$ adrenergic receptors and $\mathrm{M}_{2}$-muscarinic $\mathrm{AcCh}$ receptors may have more than one function (Yatani et al., 1987b, c). The same applies to neuropeptide $Y$ (Ewald et al., 1988) and opioid receptors (Hescheler et al., 1987). Another example is that $\alpha_{1}$-adrenergic stimulation activates independently both phospholipase $\mathrm{C}$ and phospholipase $\mathrm{A}_{2}$ (Burch et al., 1986; for other examples see Knecht el al., 1987 and Cotecchia et al., 1990)

Since single cells can express multiple subtypes of the same receptor, as demonstrated in glioma cells which express both $\beta_{1}$ - and $\beta_{2}$-adrenergic receptors (Homburger et al., 1981), these multiple actions of a given hormone were ascribed to receptor heterogeneity. In some cases structurally and functionally different receptors were distinguished on the basis of high and low affinity for one given hormone. For example, in the case of glucagon receptors on hepatocytes, high-affinity/ low-capacity receptors were believed to be associated with the formation of inositol trisphosphate and rise in intracellular $\mathrm{Ca}^{2+}$, whereas those of lower affinity but higher capacity were thought to be responsible for adenylate cyclase activation and a rise in cAMP (Wakelam et al., 1986).

A similar situation was observed in platelets in the case of prostaglandin $E_{1}$ receptors where the lower-affinity receptor was again associated with adenylate cyclase, while the function of the higher-affinity receptor remained unclear (Mruk et al., 1982). On the other hand, glucagon and prostaglandin $E_{1}$ receptors on MDCK cells are activated by their respective agonists, apparently in about the same range of concentrations, but each appears to be responsible for a concomitant rise in intracellular $\mathrm{Ca}^{2+}$ and cAMP, suggesting that a single receptor may activate more than one G-protein (Kurstjens et al. 1990). This was first demonstrated in reconstitution experiments where it was shown that rhodopsin stimulated not only GTP hydrolysis by transducin, but also by a mixture of human erythrocyte $\mathrm{G}_{\mathrm{i}}-2$ and $\mathrm{G}_{\mathrm{i}}-3$ proteins (Cerione et al., 1985). Later, it was shown that a $\beta_{1}$-adrenoceptor interacts not only with $G_{s}$, its true partner, but also with $G_{0}$ (Kurstjens et al., 1991).

The most convincing evidence that a single receptor may indeed interact with more than one type of G-protein comes from experiments with a cardiac $\mathrm{M}_{2}$-muscarinic acetylcholine receptor clone with which cells were transfected. Activation of the $\mathrm{M}_{2}$-receptor in the transfected cells by acetylcholine resulted in inhibition of adenylate cyclase, i.e. activation of $G_{i}$ and likewise in stimulation of phospholipase $\mathrm{C}$ by another $\mathrm{G}$ protein (named $\mathrm{G}_{\mathrm{p}}$ ) (Ashkenazi et al., 1987). Therefore, it is quite likely that one receptor can couple to more than one $G$ protein and regulate more than one effector function. Thus the capability of one G-protein-linked hormone receptor to activate two or more separate signal transmission pathways, as for example the neuropeptide $Y_{1}$ receptor (Aakerlund et al., 1990), could therefore be interpreted as a functional correlate to the structural diversity of transducing elements, on the one hand, and as reflecting structural heterogeneity of receptors, on the other.

While the evidence is impressive that one receptor can interact with more than one G-protein, it is still a matter of speculation whether one effector might interact with more than one G-protein. This is shown in Fig. 1C. Considering the different structural and functional properties of well characterized targets, such as cGMP phosphodiesterase, phospholipase $C$ and adenylate cyclase, it would seem less likely that one $G$-protein can interact productively with more than one effector system. But this problem remains open until we know how many isoforms of effectors exist and how different they are structurally. This situation is depicted in Fig. $1 \mathrm{~B}$

Notwithstanding the examples cited above, the information presently available does not allow us to distinguish sharply between these possibilities or exclude one or the other. For example, it is still a matter of speculation whether subtypes of one receptor species with different affinities and $B_{\max }$ values for ligands are responsible for different functions at the cellular level, or whether functional pleiotropy is due to the fact that more than one $\mathrm{G}$-protein couples to each receptor. Both situations may conceivably exist and could contribute to functional diversity and accommodate the ever widening spectrum of cellular processes in which G-proteins play a crucial role (see Table 1 ). In order to clarify multiple receptor-effector-G-protein interactions, it will be necessary to characterize each cell type with respect to structure and function of receptors and $\mathrm{G}$-proteins. Moreover, since it is to be expected that differences in interaction parameters of components of a signal transmission chain are quite subtle, more precise and quantitative assays will be needed.

\section{Outlook}

The purpose of this review is to make clear how profoundly the proliferation of structural information on receptors, $G$ proteins and targets revealing great heterogeneity has influenced our thinking on hormone action, thinking which was previously dominated primarily by the pharmacologists' interpretation of selectivity and specificity of hormone binding and its consequences. The structural heterogeneity of receptors and $\mathrm{G}$-proteins brought to light by the recombinant DNA technology points to a high level of complexity. Perhaps this complexity might have been anticipated from a consideration of the pleiotropic effects of hormones, but it creates new problems not appreciated until now and points to the need 
for a different kind of information in order to tackle the problems of structural heterogeneity and ambiguity of coupling interactions in the course of receptor activation and amplification of hormone action.

At the cellular level, use can be made of mutant cells where one or the other component of a hormonal signal chain is mutated or deleted. Moreover, structurally defined and characterized isoforms can be expressed in heterologous cells and the functional consequences studied. The other approach aims at the molecular level: in order to detect multiple receptor-effector-G-protein interactions and test proteins engineered by site-directed mutagenesis, it will be necessary to use more precise and quantitative assays in order to define the limits within which partners can actually interact and recognize each other. Thus, these assays must allow us to distinguish subtly among several interacting partners on the basis of differences in affinities and kinetics.

Use can be made of reconstituted proteoliposomes. Recently, fluorescence energy transfer was applied in a study of rhodopsin-G-protein interaction (Borochov-Neori and Montal, 1989). This is also being used in our laboratory (unpublished results) for the study of interactions of G-protein subunits with the $\beta$-adrenoceptor using liposomes reconstituted with pure separate receptor and $\alpha$ - and $\beta \gamma$-subunits. This is only one among several experimental approaches which could be pursued.

However, since all the important questions which need to be answered are centered around the structural complementarity between G-proteins and their respective partners, receptors and targets, three-dimensional structures of the proteins interacting in signal transmission chains in membranes would provide the most convincing information. Without three-dimensional structures of receptors, G-proteins, target enzymes and channels, we will not be able to translate structural properties into functional characteristics. No detailed Xray structures of membrane proteins, which are constituents of signal transduction pathways are yet available with the exception of ras p21 (Pai et al., 1989, 1990) whose role in signal transmission is, however, not clear. Only when structural information at the molecular level is available, as it is for hemoglobin and a few other allosterically regulated key enzymes of metabolism (for a review see Perutz, 1989), will the confusing and at present overwhelming complexity of possible interactions between participants in signal transmission pathways become interpretable.

Just a few basic patterns of structure/function relationships might emerge and restore order. This hope is based on the assumption that G-proteins and their coupling partners, because of their physiological importance, are proteins with conserved functional domains. Accordingly, one might expect that some basic mechanisms for cooperative conformational transitions have emerged in the course of evolution which determine interactions between $\alpha-, \beta$ - and $\gamma$-subunits on the one hand and between these subunits and a variety of receptors and effectors on the other. Once we understand these mechanisms, it will be possible to construct a dense, versatile and responsive regulatory network for transmitter and hormone control of cell function on the basis of a few principles for structural transitions.

The pioneering phase, in which classical biochemistry and recombinant cDNA technology brought us the isolation and characterization of G-proteins, receptors, channels and target enzymes, is coming to an end. The biochemical information must now be supplemented by three-dimensional structural analyses of these membrane proteins. A beginning has already been made in the case of a complex membraneous multicomponent system, the photosynthetic reaction center in Rhodopseudomonas viridis (Deisenhofer and Michel, 1989). The $\mathrm{X}$-ray crystallographers are now called upon to meet this challenge.

Work from this laboratory is supported by the Sonderforschungsbereich (SFB 176, project A1 to E. J.M.H.), by the Deutsche Forschungsgemeinschaft (DFG, grants He 22/44-1 to E. J.M.H., Bo 910/1-1 to F.B.) and by Fonds der Chemischen Industrie e.V. E. N. wishes to acknowledge support from the DFG (through SFB 223, project D3) and E.J.M.H. support from the Volkswagen Stiftung through a personal stipend. We wish to thank Mrs C. Möller for secretarial help, helping with the literature search and for typing the manuscript.

\section{References}

Aakerlund, L., Gether, U., Fuhlendorff, J., Schwartz, T. W. \& Thastrup, O. (1990) FEBS Lett. 260, 73 - 78.

Ahlquist, R. P. (1948) Am. J. Physiol. 153, 586- 592.

Aktories, K., Weller, V. \& Chhatwal, G. S. (1987) FEBS Lett. 2I2, $109-113$.

Allende, J. E. (1988) FASEB J. 2, 2356-2367.

Amatruda, T., Gautam, N., Fong, H. K. W., Northup, J. K. \& Simon, M. I. (1988) J. Biol. Chem. 263, 5008-5011.

Ashkenazi, A., Winslow, J. W., Peralta, E. G., Peterson, G. L., Schimerlik, M. I., Capon, D. J. \& Ramachandran, J. (1987) Science 238, 672-675.

Axelrod, J., Burch, R. M. \& Jelsema, C. L. (1988) Trends Neurosci. $11,117-123$.

Bakalyar, H. A. \& Reed, R. R. (1990) Science 250, 1403-1406.

Balch, W. E. (1990) Trends Biochem. Sci. 15, 473-477.

Ballester, R., Michaeli, T., Ferguson, K., Xu, H.-P., McCormick, F. \& Wigler, M. (1989) Cell 59, $681-686$.

Barbacid, M. (1987) Annu. Rev. Biochem. 56, $779-828$.

Barnard, E. A. (1988) Nature 335, 301-302.

Beavo, J. A. (1988) Adv. Second Messenger Phosphoprotein Res. 22.

Berridge, M. J. \& Irvine, R. F. (1989) Nature 341, 197-205.

Bertrand, P., Sanford, J., Rudolph, U., Codina, J. \& Birnbaumer, L. (1990) J. Biol. Chem. 265, 18576-18580.

Bevan, J. A., Bevan, R. D. \& Shreeve, S. M. (1989) FASEB J. 3, $1696-1704$.

Birnbaumer, L. (1990) FASEB J. 4, 3178-3188.

Birnbaumer, L., Yatani, A., Codina, J., VanDongen, A., Graf, R., Mattera, R., Sanford, J. \& Brown, A. M. (1989) in Molecular mechanisms of hormone action (Gehring, U., Helmreich, E. J. M. \& Schultz, G., eds) pp. 147-177, Springer-Verlag, Berlin.

Birnbaumer, L., Abramowitz, J. \& Brown, A. M. (1990) Biochim. Biophys. Acta 1031, 163-224.

Boege, F., Ward, M., Jürss, R., Hekman, M. \& Helmreich, E. J. M. (1988) J. Biol. Chem. 263, 9040-9049.

Böni-Schnetzeler, M., Rubin, J. B. \& Pilch, P. F. (1986) J. Biol. Chem. $261,15281-15287$.

Borochov-Neori, H. \& Montal, M. (1989) Biochemistry 28, 1711 1718.

Boulay, F., Tardif, M., Brouchon, L. \& Vignais, P. (1990) Biochemistry 29, $11123-11133$.

Bourne, H. R., Sanders, D. A. \& McCormick, F. (1990) Nature 348, $125-132$.

Boyer, J. L., Downes, C. P. \& Harden, T. K. (1989) J. Biol. Chem. $264,884-890$.

Braun, U., Habermann, B., Just, I., Aktories, K. \& Vandekerckhove, J. (1989) FEBS Lett. 243, 70-76.

Bray, P., Carter, A., Simons, C., Guo, V., Puckett, C., Kamholz, J., Spiegel, A. \& Nirenberg, M. (1986) Proc. Natl Acad. Sci. USA 83, 8893-8897.

Bray, P., Carter, A., Guo, V., Puckett, C., Kamholz, J., Spiegel, A. \& Nirenberg, M. (1987) Proc. Natl Acad. Sci. USA 84, 5115-5119.

Brenner, M. B., Trowbridge, I. S. \& Strominger, J. L. (1985) Cell 40, 183-190. 
Brown, A. M. \& Birnbaumer, L. (1988) Am. J. Physiol. 254, H $401-$ H410.

Burch, R. M., Luini, A. \& Axelrod, J. (1986) Proc. Natl Acad. Sci. USA 83, $7201-7205$.

Burgermeister, W., Hekman, M. \& Helmreich, E. J. M. (1982) J. Biol. Chem. 257, 5306-5311.

Burgoyne, R. D. (1989) Trends Biochem. Sci. 14, 394-396.

Burgoyne, R. D. (1990) Annu. Rev. Physiol. 52, 647-659.

Burnstock, G. (1978) in Cell membrane receptors for drugs and hormones: a multidisciplinary approach (Straub, R. W. \& Bolis, L., eds) pp. 107-118, Raven Press, New York.

Burnstock, G. \& Kennedy, C. (1985) Gen. Pharmacol. 16, 433-440.

Carpenter, C. L. \& Cantley, L. C. (1990) Biochemistry 29, $11147-$ 11156.

Casey, P. J. \& Gilman, A. G. (1988) J. Biol. Chem. 263, 2577-2580.

Casey, P. J., Graziano, M. P. \& Gilman, A. G. (1989) Biochemistry $28,611-616$.

Cerione, R. A., Staniszewski, C., Benovic, J. L., Lefkowitz, R. J., Caron, M. C., Gierschik, P., Somers, R., Spiegel, A. L., Codina, J. \& Birnbaumer, L. (1985) J. Biol. Chem. 260,1493-1500.

Chang, H. W., Bock, E. \& Neumann, E. (1984) Biochemistry 23, $4546-4556$

Changeux, J.-P., Devillers-Thiery, A. \& Chemouilli, P. (1984) Science $225,1335-1345$.

Chardin, P., Boquet, P., Madaule, P., Popoff, M. R., Rubin, E. J. \& Gill, D. M. (1989) EMBO J. 8,1087-1092.

Chavrier, P., Parton, R. G., Hauri, H.-P., Simons, K. \& Zerial, M. (1990) Cell 62, 317-329.

Cheung, A. H., Sigal, I. S., Dixon, R. A. F. \& Strader, C. D. (1989) Mol. Pharmacol. 35, 132-138.

Chinkers, M., Garbers, D. L., Chang, M. S., Lowe, D. G., Chin, H., Goeddel, D. V. \& Schulz, S. (1989) Nature 338, $78-83$.

Ciaraldi, T. P. \& Maisel, A. (1989) Biochem. J. 264, 389-396.

Cochet, C., Kashles, O., Chambaz, E. M., Borrello, I., King, C. R. \& Schlessinger, J. (1988) J. Biol. Chem. 263, 3290-3295.

Codina, J., Yatani, A., Grenet, D., Brown, A. M. \& Birnbaumer, L. (1987) Science 236, 442

Cotecchia, S., Schwinn, D. A., Randall, R. R., Lefkowitz, R. J., Caron, M. G. \& Kobilka, B. K. (1988) Proc. Natl Acad. Sci. USA $85,7159-7163$

Cotecchia, S., Kobilka, B. K., Daniel, K. W., Nolan, R. D., Lapetina, E. Y., Caron, M. G., Lefkowitz, R. J. \& Regan, J. W. (1990) J. Biol. Chem. 265, 63-69.

Czech, M. P. (1985) Annu. Rev. Physiol. 47, 357-381

Czech, M. P., Klarlund, J. K., Yagaloff, K. A., Bradford, A. P. \& Lewis, R. E. (1988) J. Biol. Chem. 263, $11017-11020$.

Deisenhofer, J. \& Michel, H. (1989) Science 245, 1463- 1473.

Devreotes, P. (1989) Science 245, 1054- 1058.

Dietzel, C. \& Kurjan, J. (1987) Cell 50, $1001-1010$.

Dixon, R. A. F., Sigal, I. S., Rands, E., Register, R. B., Candelore, M. R., Blake, A. D. \& Strader, C. D. (1987) Nature 326, $73-77$.

Dixon, R. A. F., Strader, C. D. \& Sigal, I. S. (1988) Annu. Rep. Med. Chem. 23, 221-233.

Dohlman, H. G., Caron, M. G., DeBlasi, A., Frielle, T. \& Lefkowitz, R. J. (1990) Biochemistry 29, 2335-2342.

Dumont, J. E., Jauniaux, J.-C. \& Roger, P. P. (1989) Trends Biochem. Sci. $14,67-71$

Eimerl, S., Schramm, M., Lok, S., Goodman, M., Khan, M. \& Melmon, K. (1987) Biochem. Pharmacol. 36, 3523-3527.

Eliot, L. S., Dudai, Y., Kandel, E. R. \& Abrams, T. W. (1989) Proc. Natl Acad. Sci. USA 86, 9564-9568.

Emorine, L. J., Marullo, S., Briend-Sutren, M.-M., Patey, G., Tate, K., Delavier-Klutchko, C. \& Strosberg, A. D. (1989) Science 245, $1118-1121$

Evans, T., Fawzi, A., Fraser, E. D., Brown, M. L. \& Northup, J. K. (1987) J. Biol. Chem. 262, 176-181.

Ewald, D. A., Sternweis, P. C. \& Miller, R. J. (1988) Proc. Natl Acad. Sci. USA 85, 3633-3637.

Fain, J. N., Wallace, M. A. \& Wojcikiewicz, R. J. H. (1988) FASEB J. 2,2569-2574

Fanger, B. O., Stephens, J. E. \& Staros, J. V. (1989) FASEB J. 3, $71-$ 75 .
Fargin, A., Raymond, J. R., Lohse, M. J., Kobilka, B. K., Caron, M. G. \& Lefkowitz, R. J. (1988) Nature 335, 358-360.

Feder, D., Im, M.-J., Klein, H. W., Hekman, M., Holzhöfer, A., Dees, C., Levitzki, A., Helmreich, E. J. M. \& Pfeuffer, T. (1986) EMBO J. 5, 1509-1514.

Ferris, C. D., Huganir, R. L., Supattapone, S. \& Snyder, S. H. (1989) Nature 342, 87-89.

Fischer v. Mollard, G., Mignery, G. A., Baumert, M., Perin, M. S., Hanson, T. J., Burger, P. M., Jahn, R. \& Südhof, T: C. (1990) Proc. Natl Acad. Sci. USA 87, 1988-1992.

Fong, H. K., Amatruda, T. T., Birren, B. W. \& Simon, M. I. (1987) Proc. Natl Acad. Sci. USA 84, 3792-3796.

Fong, H. K., Yashimoto, K. K., Eversole-Cire, P. \& Simon, M. I. (1988) Proc. Natl Acad. Sci. USA 85, 3066-3070.

Fraser, C. M. (1989) J. Biol. Chem. 264, 9266-9270.

Fraser, C. M., Kervalage, A. R., Mariani, A. P. \& Venter, J. C. (1987) Proteins: Struct. Funct. Genet. 2, 34-41.

Freissmuth, M., Casey, P. J. \& Gilman, A. G. (1989) FASEB J. 3, $2125-2131$

Frieden, C. (1971) Annu. Rev. Biochem. 40, 653-696.

Frielle, T., Collins, S., Daniel, K., Caron, M. G., Lefkowitz, R. J. \& Kobilka, B. K. (1987) Proc. Natl Acad. Sci. USA 84, 7920 - 7924.

Fung, B. K.-K., Yamane, H. K., Ota, I. M. \& Clarke, S. (1990) FEBS Lett. 260, 313-317.

Furuichi, T., Yoshikawa, S., Miyawaki, A., Wada, K., Maeda, N. \& Mikoshiba, K. (1989) Nature 342, 32-38.

Gallwitz, D., Donath, C. \& Sander, C. (1983) Nature 306, 704-707.

Gao, B., Gilman, A. G. \& Robishaw, J. D. (1987) Proc. Natl Acad. Sci. USA 84, 6122-6125.

Gautam, N., Baetscher, M., Aebersold, R. \& Simon, M. I. (1989) Science 244, $971-974$.

Gautam, N., Northup, J., Tamir, H. \& Simon, M. I. (1990) Proc. Natl Acad. Sci. USA 87, 7973-7977.

Gill, D. L. (1989) Nature 342, 16-18.

Gilman, A. G. (1987) Annu. Rev. Biochem. 56, 615-649.

Gilman, A. G. (1989) J. Am. Med. Assoc. 262, 1819 - 1825.

Gomperts, B. P. (1990) Annu. Rev. Physiol. 52, 591-606.

Gottesman, M. M. \& Pastan, I. (1988) J. Biol. Chem. 263, $12163-$ 12166.

Graziano, M. P., Freissmuth, M. \& Gilman, A. G. (1989) J. Biol. Chem. 264, 409-418.

Hall, A. (1990) Cell 61, $921-923$.

Hamm, H. E., Deretic, D., Arendt, A., Hargrave, P. A., Koenig, B. \& Hofmann, K. P. (1988) Science 241, 832-835.

Hanley, M. R. (1989) Nature 340, 97.

Harris, B. A., Robishaw, J. D., Mumby, S. M. \& Gilman, A. G. (1985) Science 229, 1274-1277.

Hartmann, E., Rapoport, T. A. \& Lodish, H. F. (1989) Proc. Natl Acad. Sci. USA 86, 5786-5790.

Hausdorff, W. P., Caron, M. G. \& Lefkowitz, R. J. (1990a) FASEB J. 4, $2881-2889$.

Hausdorf, W. P., Hnatowich, M., O'Dowd, B. F., Caron, M. G. \& Lefkowitz, R. J. (1990b) J. Biol. Chem. 265, 1388-1393.

Heidenreich, K. A., Weiland, G. A. \& Molinoff, P. B. (1982) J. Biol. Chem. 257, 804-810

Heithier, H., Jacggi, K. A., Ward, L. D., Cantrill, R. C. \& Helmreich, E. J. M. (1988) Biochimie 70, 687-694.

Hekman, M., Holzhöfer, A., Gierschik, P., Im, M.-J., Jakobs, K.-H., Pfeuffer, T. \& Helmreich, E. J. M. (1987) Eur. J. Biochem. 169, $431-439$

Henderson, R. \& Unwin, P. N. T. (1975) Nature 257, 23-32.

Henderson, R., Baldwin, J. M., Ceska, T. A., Zemlin, F., Beckmann, E. \& Downing, K. H. (1990) J. Mol. Biol. 213, 899-929.

Henis, Y. I., Hekman, M., Elson, E. L. \& Helmreich, E. J. M. (1982) Proc. Natl Acad. Sci. USA 79, 2907-2910.

Herlemann, J. (1989) Ph. D. thesis, Faculty of Chemistry, University of Bielefeld.

Herskowitz, F. \& Marsh, L. (1987) Cell 50, 995-997.

Hescheler, J., Rosenthal, W., Trautwein, W. \& Schultz, G. (1987) Nature 325, 445-447.

Heyworth, C. M., Whetton, A. D., Wong, S., Martin, B. R. \& Houslay, M. D. (1985) Biochem. J. 228, 593-603. 
Homburger, V., Lucas, M., Rosenbaum, E., Vassent, G. \& Bockaert, J. (1981) Mol. Pharmacol. 20, 463-469.

Huang, R.-R. C., Dehaven, R. N., Cheung, A. H., Diehi, R. E., Dixon, R. A. F. \& Strader, C. D. (1990) Mol. Pharmacol. 37, $304-310$,

Hurwitz, R. L., Bunt-Milam, A. H. \& Beavo, J. A. (1984) J. Biol. Chem. 259, 8612-8618.

Hurwitz, R. L., Bunt-Milam, A. H., Chang, M. L. \& Beavo, J. A. (1985) J. Biol. Chem. 260, 568-573.

Im, M.-J., Holzhöfer, A., Böttinger, H., Pfeuffer, T. \& Helmreich, E. J. M. (1988) FEBS Lett. 227, $225-229$.

Inanobe, A., Shibasaki, H., Takahashi, K., Kobayashi, I., Tomita, U., Ui, M. \& Katada, T. (1990) FEBS Lett. 263, 369-372.

Itoh, H., Kozasa, T., Nagata, S., Nakamura, S., Katada, T., Ui, M., Iwai, S., Ohtsuka, E., Kawasaki, H., Suzuki, K. \& Kaziro, Y. (1986) Proc. Natl Acad. Sci. USA 83, 3776-3780.

Itoh, H., Toyama, R., Kozasa, T., Tsukamoto, T., Matsuoka, M. \& Kaziro, Y. (1988) J. Biol. Chem. 263, 6656-6664.

Iyengar, R. (1981) J. Biol. Chem. 256, $11041-11050$.

Jakobs, K. H., Bauer, S. \& Watanabe, Y. (1985) Eur. J. Biochem. 151, $425-430$

James, G. \& Olson, E. N. (1990) Biochemistry 29, 2623-2634.

Jones, D. T. \& Reed, R. R. (1987) J. Biol. Chem. 262, 14241 - 14249.

Jones, D. T. \& Reed, R. R. (1989) Science 244, 790-795.

Jones, T. L. Z., Simonds, W. F., Merendino, Jr J. J., Brann, M. R. \& Spiegel, A. M. (1990) Proc. Natl Acad. Sci. USA 87, 568-572.

Kahn, R. A. \& Gilman, A. G. (1986) J. Biol. Chem. 26I, 7906-7911

Katada, T., Gilman, A. G., Watanabe, Y., Bauer, S. \& Jakobs, K. H. (1985) Eur. J. Biochem. 151, $431-437$.

Katada, T., Oinuma, M. \& Ui, M. (1986) J. Biol. Chem. 261, 52155221.

Katan, M., Kriz, R. W., Totty, N., Philp, R., Meldrum, E., Aldape, R. A., Knopf, J. L. \& Parker, P. J. (1988) Cell 54, 171 - 177.

Kelvin, D. J., Simard, G., Tai, H. H., Yamaguchi, T. P. \& Connolly, J. A. (1989) J. Cell. Biol. 108, 159-167.

Kiehl, R., Varsányi, M. \& Neumann, E. (1987) Biochem. Biophys. Res. Commun. 147, $1251-1258$.

Kikuchi, A., Yamamoto, K., Fujita, T. \& Takai, Y. (1988) J. Biol Chem. 263, 16303-16308.

Kim, D., Lewis, D. L., Graziadei, L., Neer, E. J., Bar-Sagi, D. \& Clapham, D. E. (1989) Nature 337, 557-560.

Klein, P. S., Sun, T. J., Saxe, III, C. L., Kimmel, A. R., Johnson, R. L. \& Devreotes, P. N. (1988) Science 241, 1467-1472.

Knecht, M., Feng, P. \& Catt, K. J. (1987) Endocrinology I20, 1243 1251.

Kobilka, B. K., Kobilka, T. S., Daniel, K., Regan, J. W., Caron, M. G. \& Lefkowitz, R. J. (1988) Science 240, 1310-1316.

Kojima, I., Kitaoka, M. \& Ogata, E. (1989) FEBS Lett. 258, 150-152.

Korner, M., Gilon, C. \& Schramm, M. (1982) J. Biol. Chem. 257, $3389-3396$.

Kozasa, T., Itoh, H., Tsukamoto, T.\& Kaziro, Y. (1988) Proc. Natl Acad. Sci. USA 85, 2081-2085.

Krupinski, J., Coussen, F., Bakalyar, H. A., Tang, W.-J., Feinstein, P. G., Orth, K., Slaughter, C., Reed, R. R. \& Gilman, A. G. (1989) Science 244, 1558-1564.

Kurstjens, N. P., Heithier, H., Cantrill, R. C., Hahn, M. \& Boege, F. (1990) Biochem. Biophys. Res. Commun. 167, 1162-1169.

Kurstjens, N. P., Fröhlich, M., Dees, C., Cantrill, R. C., Hekman, M. \& Helmreich, E. J. M. (1991) Eur. J. Biochem. 197, 167-176.

Landis, C. A., Masters, S. B,, Spada, A., Pace, A. M., Bourne, H. R. \& Vallar, L. (1989) Nature 340, 692-696.

Lefkowitz, R. J. \& Caron, M. G. (1988) J. Biol. Chem. 263, 4993-4996.

Lerea, C. L., Somers, D. E., Hurley, J. B., Klock, I. B. \& Bunt-Milan, A. H. (1986) Science 234, 77-80.

Levine, M. A., Smallwood, P. M., Moen, Jr, P. T., Helman, L. J. \& Ahn, T. G. (1990) Proc. Natl Acad. Sci. USA 87, 2329-2333.

Levitzki, A. (1988) Science 24l, 800-806.

Lochrie, M. A. \& Simon, M. I. (1988) Biochemistry 27, 4957-4965.

Lochrie, M. A., Hurley, J. B. \& Simon, M. I. (1985) Science 228, 96-99.

Lodish, H. F. (1988) Trends Biochem. Sci. 13, 332-334.

Logothetis, D. E., Kurachi, Y., Galper, J., Neer, E. J. \& Clapham, D. E. (1987) Nature $325,321-326$.
Logothetis, D. E., Kim, D., Northup, J. K., Neer, E. J. \& Clapham, D. E. (1988) Proc. Natl Acad. Sci. USA 85, 5814-5818.

Lohse, M. J., Benovic, J. L., Codina, J., Caron, M. G. \& Lefkowitz, R. J. (1990) Science 248, 1547.

Loosfelt, H., Misrahi, M., Atger, M., Salesse, R., Hai-Luu Thi, M. T. V., Jolivet, A., Guiochon-Mantel, A., Sar, S., Jallal, B., Garnier, J. \& Milgrom, E. (1989) Science 245, 525-528.

Maltese, W. A. \& Robishaw, J. D. (1990) J. Biol. Chem. 265, 18071 18074.

Marbach, I., Bar-Sinai, A., Minich, M. \& Levitzki, A. (1990) J. Biol. Chem. 265, 9999-10004.

Marullo, S., Delavier-Klutchko, C., Eshdat, Y., Strosberg, A. D. \& Emorine, L. (1988) Proc. Natl Acad. Sci. USA 85, 7551 - 7555.

Masu, Y., Nakayama, K., Tamaki, H., Harada, Y., Kuno, M. \& Nakanishi, S. (1987) Nature 329, 836-838.

Matsuoka, M., Itoh, H., Kozasa, T. \& Kaziro, Y. (1988) Proc. Natl Acad. Sci. USA 85, 5384-5388.

Mattera, R., Codina, J., Crozat, A., Kidd, V., Woo, S. L. C. \& Birnbaumer, L. (1986) FEBS Lett. 206, 36-42.

Mattera, R., Graziano, M. P., Yatani, A., Zhou, Z., Graf, R., Codina, J., Birnbaumer, L., Gilman, A. G. \& Brown, A. M. (1989) Science $243,804-807$.

May, D. C., Ross, E. M., Gilman, A. G. \& Smigel, M. D. (1985) $J$. Biol. Chem. 260, 15829-15833.

McCormick, F. (1989) Cell 56, 5-8.

McFarland, K. C., Sprengel, R., Phillips, H. S., Köhler, M., Rosemblit, N., Nikolics, K., Segaloff, D. L. \& Seeburg, P. H. (1989) Science 245, 494-499.

Medynski, D. C., Sullivan, K., Smith, D., Van Dop, C., Chang, F.H., Fung, B. K.-K., Seeburg, P. H. \& Bourne, H. R. (1985) Proc Natl Acad. Sci. USA 82,4311-4315.

Melancon, P., Glick, B. S., Malhotra, V., Weidman, P. J., Serafini, T., Gleason, M. L., Orci, L. \& Rothman, J. E. (1987) Cell 5, $1053-1062$.

Mohell, N. \& Dicker, A. (1989) Biochem. J. 261, 401-405.

Mollner, S. \& Pfeuffer, T. (1988) Eur. J. Biochem. 171, 265-271

Moxham, C. P., Ross, E. M., George, S. T. \& Malbon, C. C. (1988) Mol. Pharmacol. 33, 486-492.

Mruk, J., Bakardjieva, A. \& Burgermeister, W. (1982) Hoppe-Seyler's Z. Physiol. Chem. 363, 745-756.

Mumby, S. M., Heukeroth, R. O., Gordon, J. I. \& Gilman, A. G (1990a) Proc. Natl Acad. Sci. USA 87, 728-732.

Mumby, S. M., Casey, P. J., Gilman, A. G., Gutowski, S. \& Sternweis, P. C. (1990 b) Proc. Natl Acad. Sci. USA 87, 5873-5877.

Nair, B. G., Rashed, H. M. \& Patel, T. B. (1989) Biochem. J. 264, $563-571$

Nakafuku, M., Itoh, H., Nakamura, S. \& Kaziro, Y. (1987) Proc. Natl Acad. Sci. USA 84, 2140-2144.

Nakafuku, M., Obara, T., Kaibuchi, K., Miyajima, I., Miyajima, A., Itoh, H., Nakamura, S., Arai, K.-I., Matsumoto, K. \& Kaziro, Y. (1988) Proc. Natl Acad. Sci. USA 85, 1374-1378.

Nakajima, Y., Nakajima, S. \& Inoue, M. (1988) Proc. Natl Acad. Sci. USA 85, 3643-3647.

Nakano, A. \& Muramatsu, M. (1989) J. Cell Biol. 109, $2677-2691$.

Neer, E. J. \& Clapham, D. E. (1988) Nature 333, 129-134.

Neumann, E. (1973) Angew. Chem. 85, 430-444; Angew. Chem. Int. Ed. Engl. 12, 356-369.

Neumann, E., Boldt, E., Rauer, B., Wolf, H. \& Chang, H. W. (1988) Bioelectrochem. Bioenerg. 20, 45-56.

Nukada, T., Tanabe, T., Takahashi, H., Noda, M., Hirose, T., Inayama, S. \& Numa, S. (1986a) FEBS Lett. 195, 220 -- 224

Nukada, T., Tanabe, T., Takahashi, H., Noda, M., Haga, K., Haga, T., Ichiyama, A., Kangawa, K., Hiranaga, M., Matsuo, H. \& Numa, S. (1986b) FEBS Lett. 197, 305-310.

O'Dowd, B. F., Hnatowich, M., Regan, J. W., Leader, W. M., Caron, M. G. \& Lefkowitz, R. J. (1988) J. Biol. Chem. 263, 1598515992.

O’Dowd, B. F., Hnatowich, M., Caron, M. G., Lefkowitz, R. J. \& Bouvier, M. (1989) J. Biol. Chem. 264, 7564-7569.

Olsen, R. W. \& Tobin, A. J. (1990) FASEB J. 4, 1469-1480.

Olson, T. S. \& Lane, M. D. (1989) FASEB J. 3, 1618-1624.

Pai, E. F., Kabsch, W., Krengel, U., Holmes, K. C., John, J. \& Wittinghofer, A. (1989) Nature 341, 209-214. 
Pai, E. F., Krengel, U., Petsko, G. A., Goody, R. S., Kabsch, W. \& Wittinghofer, A. (1990) EMBO J. 9, 2351 - 2359.

Palm, D., Münch, G., Dees, C. \& Hekman, M. (1989) FEBS Lett. 254, 89-93.

Palm, D., Münch, G., Malek, D., Dees, C. \& Hekman, M. (1990) FEBS Lett. 261, 294-298.

Pang, I.-H. \& Stcrnweis, P. C. (1990) J. Biol. Chem. 265, $18707-$ 18712.

Perutz, M. F. (1989) Q. Rev. Biophys. 22, 139-237.

Pfeuffer, T. \& Hclmreich, E. J. M. (1988) Curr. Top. Cell. Regul. 29, $129-216$.

Pfeuffer, E., Mollner, S. \& Pfeuffer, T. (1985) EMBO J. 4, $6375-$ 6379.

Pfeuffer, E., Mollner, S., Lancet, D. \& Pfeuffer, T. (1989) J. Biol. Chem. 264, 18803-18807.

Pobiner, B. F., Hewlett, E. L. \& Garrison, J. C. (1985) J. Biol. Chem. $260,16200-16209$

Portenier, M., Hertel, C., Muller, P. \& Staehelin, M. (1984) J. Receptor Res. 4, 103-111.

Price, S. R., Murtagh, Jr J. H., Tsuchiya, M., Serventi, I. M., Van Meurs, K. P., Angus, C. W., Moss, J. \& Vaughan, M. (1990) Biochemistry 29, $5069-5076$.

Provost, N. M., Somers, D. E. \& Hurley, J. B. (1988) J. Biol. Chem. $263,12070-12076$.

Pupillo, M., Kumagai, A., Pitt, G. S., Firtel, R. A. \& Devreotes, P. N. (1989) Proc. Natl Acad. Sci. USA 86, 4892-4896.

Regan, J. W., Kobilka, T. S., Yang-Feng, T. L., Caron, M. G., Lefkowitz, R. J. \& Kobilka, B. K. (1988) Proc. Natl Acad. Sci. USA 85, 6301-6305.

Robishaw, J. D., Smigel, M. D. \& Gilman, A. G. (1986a) J. Biol. Chem. 261,9587-9590.

Robishaw, J. D., Russell, D. W., Harris, B. A., Smigel, M. D. \& Gilman, A. G. (1986b) Proc. Natl Acad. Sci. USA 83, $1251-$ 1255.

Robishaw, J. D., Kalman, V. K., Moomaw, C. R. \& Slaughter, C. A. (1989) J. Biol. Chem. 264, 15758-15761.

Ross, P. C., Figler, R. A., Corjay, M. H., Barber, C. M., Adam, N., Harcus, D. R. \& Lynch, K. R. (1990) Proc. Natl Acad. Sci. USA $87,3052-3056$.

Rothman, J. E. \& Orci, L. (1990) FASEB J. 4, 1460-1468

Rubin, E. J., Gill, D. M., Bouquet, P. \& Popoff, M. R. (1988) Mol. Cell. Biol. 8, 418-426.

Salminen, A. \& Novick, P. J. (1987) Cell 49, 527-538.

Schlessinger, J. (1986) J. Cell. Biol. 103, 2067-2072.

Schofield, P. R., Darlison, M. G., Fujita, N., Burt, D. R., Stephenson, F. A., Rodriguez, H., Rhee, L. M., Ramachandran, J., Reale, V., Glencorse, T. A., Seeburg, P. H. \& Barnard, E. A. (1987) Nature $328,221-227$.

Schultz, G. \& Rosenthal, W. (1987) Trends in Pharmacol. Sci. 8, 351 354.

Schulz, S., Chinkers, M. \& Garbers, D. L. (1989) FASEB J. 3, $2026-$ 2035.

Sharon, M., Klausner, R. D., Cullen, B. R., Chizzonite, R.\& Leonard, W. J. (1986) Science 243, $859-863$.

Shinjo, K., Koland, J. G., Hart, M. J., Narasimhan, V., Johnson, D. I., Evans, T. \& Cerione, R. A. (1990) Proc. Natl Acad. Sci. USA $87,9853-9857$.

Staehelin, M., Simons, P., Jaeggi, K. \& Wigger, N. (1983) J. Biol. Chem. 258, 3496-3502.

Staros, J. V. (1982) Biochemistry 21,3950-3955.

Stearns, T., Willingham, M. C., Botstein, D. \& Kahn, R. A. (1990) Proc. Natl Acad. Sci. USA 87, $1238-1242$.

Sternweis, P. C. (1986) J. Biol. Chem. 261, 631-637.

Stiles, G. L., Caron, M. G. \& Lefkowitz, R. J. (1984) Physiol. Rev. $64,661-743$.

Strader, C. D., Dixon, R. A. F., Cheung, A. H., Candelore, M. R., Blake, A. D. \& Sigal, I. S. (1987a) J. Biol. Chem. 262, $16439-$ 16443.

Strader, C. D., Sigal, I. S., Register, R. B., Candelore, M. R., Rands, E. \& Dixon, R. A. F. (1987b) Proc. Natl Acad. Sci. USA 84, $4384-4388$
Strader, C. D., Sigai, I. S., Candelore, M. R., Rands, E., Hill, W. S. \& Dixon, R. A. F. (1988) J. Biol. Chem. 263, 10267-10271.

Strader, C. D., Sigal, I. S. \& Dixon, R. A. F. (1989) FASEB J. 3 , $1825-1832$.

Straub, R. E. \& Gershengorn, M. C. (1986) J. Biol. Chem. 261, $2712-$ 2717.

Strittmatter, S. M., Valenzuela, D., Kennedy, T. E., Neer, E. J. \& Fishman, M. C. (1990) Nature 344, 836-841.

Stroud, R. M., McCarthy, M. P. \& Shuster, M. (1990) Biochemistry $29,11009-11023$.

Strycr, L. (1986) Anni. Rev. Neurosci. 9, 87-119.

Sugimoto, K., Nukada, T., Tanabe, T., Takahashi, H., Noda, M., Minamino, N., Kangawa, K., Matsuo, H., Hirose, T., Inayama, S. \& Numa, S. (1985) FEBS Lett. 191, 235-240.

Suh, P.-G., Ryu, S. H., Moon, K. H., Suh, H. W. \& Rhee, S. G. (1988) Cell 54, $161-169$.

Suki, W. N., Abramowitz, J., Mattera, R., Codina, J. \& Birnbaumer, L. (1987) FEBS Lett. 220, 187-192.

Sullivan, K. A., Liao, Y.-C., Alborzi, A., Beiderman, B., Chang, F. H., Masters, S. B., Levinson, A. D. \& Bourne, H. R. (1986) Proc. Natl Acad. Sci. USA 83, 6687-6691.

Supattapone, S., Worley, P. F., Baraban, J. M. \& Snyder, S. H. (1988) J. Biol. Chem. 263, 1530-1534.

Tanabe, T., Nukada, T., Nishikawa, Y., Sugimoto, K., Suzuki, H., Takahashi, H., Noda, M., Haga, T., Ichiyama, A., Kangawa, K., Minamino, N., Matsuo, H. \& Numa, S. (1985) Nature 315, 242245.

Tanaka, K., Matsumoto, K. \& Toh-E, A. (1989) Mol. Cell. Biol. 9 , $757-768$.

Tota, M. R. \& Strader, C. D. (1990) J. Biol. Chem. 265, $16891-$ 16897.

Uhing, R. J., Prpic, V., Jiang, H. \& Exton, J. H. (1986) J. Biol. Chem. $261,2140-2146$

VanDongen, A. M. J., Codina, J., Olate, J., Mattera, R., Joho, R., Birnbaumer, L. \& Brown, A. M. (1988) Science 242, 1433-1437.

Van Haastert, P. J. M. (1987) J. Biol. Chem. 262, 3239-3243.

Vauquelin, G., Bottari, S., Kanarek, L. \& Strosberg, A. D. (1979) $J$. Biol. Chem. 254, 4462-4469.

Vogel, U. S., Dixon, R. A. F., Schaber, M. D., Diehl, R. E., Marshall, M. S., Scolnick, E. M., Sigal, I. S. \& Gibbs, J. B. (1988) Nature $335,90-93$.

Wakelam, M. J. O., Murphy, J. G., Hruby, V. G. \& Houslay, M. D (1986) Nature 323, 68-71.

Walworth, N. C., Goud, B., Kabcenell, A. K. \& Novick, P. J. (1989) EMBO J. 8, 1685-1693.

Watson, S. P., McConnell, R. T. \& Lapetina, E. G. (1984) J. Biol. Chem. 259, 13199-13202.

Wieland, T., Ulibarri, I., Gierschik, P., Hall, A., Aktories, K. \& Jakobs, K. H. (1990) FEBS Lett. 274, 111-114.

Wolfman, A. \& Macara, I. G. (1990) Science 248, 67-69.

Yamamoto, K., Kondo, J., Hishida, T., Teranishi, Y.\& Takai, Y (1988) J. Biol. Chem. 263, 9926-9932.

Yamane, H. K., Farnsworth, C. C., Xie, H., Howald, W., Fung, B. K.-K., Clarke, S., Gelb, M. H. \& Glomset, J. A. (1990) Proc. Natl Acad. Sci. USA 87, 5868-5872.

Yatani, A., Codina, J., Brown, A. M. \& Birnbaumer, L. (1987a) Science 235, $207-211$.

Yatani, A., Codina, J., Imoto, Y., Reeves, J. P., Birnbaumer, L. \& Brown, A. M. (1987 b) Science 238, 1288-1292.

Yatani, A., Codina, J., Sekura, R. D., Birnbaumer, L. \& Brown, A. M. (1987 c) Mol. Endocrinol. 1, 283-289.

Yatani, A., Mattera, R., Codina, J., Graf, R., Okabe, K., Padrell, E., lyengar, R., Brown, A. M. \& Birnbaumer, L. (1988) Nature 336, $680-682$.

Yatani, A., Okabe, K., Polakis, P., Halenbeck, R., McCormick, F. \& Brown, A. M. (1990) Cell 61, 769--776.

Yatsunami, K. \& Khorana, H. G. (1985) Proc. Natl Acad. Sci. USA $82,4316-4320$.

Yokota, Y., Sasai, Y., Tanaka, K., Fujiwara, T., Tsuchida, K., Shigemoto, R., Kakizuka, A., Ohkubo, H. \& Nakanishi, S. (1989) J. Biol. Chem. 264, 17649-17652.

Zidovetzki, R., Yarden, Y., Schlessinger, J. \& Jovin, T. M. (1981) Proc. Natl Acad. Sci. USA 78,6981-6985. 